\title{
2013s-31 \\ The Connection between Wall Street and Main Street: Measurement and Implications for Monetary Policy
}

Alessandro Barattieri, Maya Eden, Dalibor Stevanovic

Série Scientifique
Scientific Series

Montréal

Septembre 2013

(C) 2013 Alessandro Barattieri, Maya Eden, Dalibor Stevanovic Tous droits réservés. All rights reserved. Reproduction partielle permise avec citation du document source, incluant la notice $($ )

Short sections may be quoted without explicit permission, if full credit, including (C) notice, is given to the source.
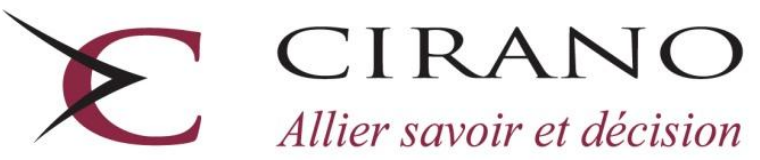

Allier savoir et décision

Centre interuniversitaire de recherche en analyse des organisations 


\section{CIRANO}

Le CIRANO est un organisme sans but lucratif constitué en vertu de la Loi des compagnies du Québec. Le financement de son infrastructure et de ses activités de recherche provient des cotisations de ses organisations-membres, d'une subvention d'infrastructure du Ministère de l'Enseignement supérieur, de la Recherche, de la Science et de la Technologie, de même que des subventions et mandats obtenus par ses équipes de recherche.

CIRANO is a private non-profit organization incorporated under the Québec Companies Act. Its infrastructure and research activities are funded through fees paid by member organizations, an infrastructure grant from the Ministère de l'Enseignement supérieur, de la Recherche, de la Science et de la Technologie, and grants and research mandates obtained by its research teams.

\section{Les partenaires du CIRANO}

\section{Partenaire majeur}

Ministère de l'Enseignement supérieur, de la Recherche, de la Science et de la Technologie

Partenaires corporatifs

Autorité des marchés financiers

Banque de développement du Canada

Banque du Canada

Banque Laurentienne du Canada

Banque Nationale du Canada

Banque Scotia

Bell Canada

BMO Groupe financier

Caisse de dépôt et placement du Québec

Fédération des caisses Desjardins du Québec

Financière Sun Life, Québec

Gaz Métro

Hydro-Québec

Industrie Canada

Investissements PSP

Ministère des Finances et de l'Économie

Power Corporation du Canada

Rio Tinto Alcan

State Street Global Advisors

Transat A.T.

Ville de Montréal

\section{Partenaires universitaires}

École Polytechnique de Montréal

École de technologie supérieure (ÉTS)

HEC Montréal

Institut national de la recherche scientifique (INRS)

McGill University

Université Concordia

Université de Montréal

Université de Sherbrooke

Université du Québec

Université du Québec à Montréal

Université Laval

Le CIRANO collabore avec de nombreux centres et chaires de recherche universitaires dont on peut consulter la liste sur son site web.

Les cahiers de la série scientifique (CS) visent à rendre accessibles des résultats de recherche effectuée au CIRANO afin de susciter échanges et commentaires. Ces cahiers sont écrits dans le style des publications scientifiques. Les idées et les opinions émises sont sous l'unique responsabilité des auteurs et ne représentent pas nécessairement les positions du CIRANO ou de ses partenaires.

This paper presents research carried out at CIRANO and aims at encouraging discussion and comment. The observations and viewpoints expressed are the sole responsibility of the authors. They do not necessarily represent positions of CIRANO or its partners. 


\title{
The Connection between Wall Street and Main Street: Measurement and Implications for Monetary Policy
}

\author{
Alessandro Barattieri ${ }^{\dagger}$, Maya Eden ${ }^{*}$, Dalibor Stevanovic ${ }^{\S}$
}

\begin{abstract}
Résumé/abstract
We propose a measure of the extent to which a financial sector is connected to the real economy. The Measure of Connectedness is a measure of composition of the assets, namely the share of the credit to the non-financial sectors over the total credit market instruments. The aggregate U.S. Measure of Connectedness declines by about $27 \%$ in the period 1952-2009. We suggest that this increase in disconnectedness between the financial sector and the real economy may have dampened the sensitivity of the real economy to monetary shocks. We present a stylized model that illustrates how interbank trading can reduce the sensitivity of lending to the entrepreneur's net worth, thereby dampening the credit channel transmission of monetary policy. Finally, we interact our measure with both a SVAR and a FAVAR for the U.S. economy, and establish that the impulse responses to monetary policy shocks are dampened as the level of connection declines.
\end{abstract}

Mots clés/Key words: Connection, financial sector, real economy, monetary policy transmission mechanism.

Codes JEL : E44, E52, G20

\footnotetext{
*We would like to thank Steve Ambler, Susanto Basu, Ben Eden, Patrick Fève, Jeffrey Frieden, Marc Giannoni, Alain Guay, Michel Juillard, Sydney C. Ludvigson, Jean-Stéphane Mésonnier, Kevin Moran, Louis Phaneuf, Thomas Philippon, Franck Portier, Federico Ravenna, Luis Serven, and seminar participants at ESG UQÀM, Bank of France, EUI, Atelier en macroeconomie CIRPÉE-DEEP-TSE 2013 and 2013 CEA annual conference for useful comments and suggestions. Elisa Martin provided outstanding research assistance. This paper does not necessarily reflect the views of the World Bank, its Executive Directors or the countries they represent.

† Corresponding Author ESG UQAM and CIRPÉE. Mail: Case Postale 8888, succursale Centre-ville, Montreal (Quebec) H3C 3P8. Tel: +1-514-987-3000 (0850\#). Fax: +1-514-987-8494.

E-mail: barattieri.alessandro@uqam.ca

$\$$ The World Bank. Macroeconomics and Growth Research Group. 1818 H st. NW. Washington, DC. Tel: +1-857-246-9722. E-mail: meden@worldbank.org

${ }^{\S}$ ESG UQAM, CIRPÉE and CIRANO. Mail: Case Postale 8888, succursale Centre-ville Montreal (Quebec) H3C 3P8. Tel: +1-514-987-3000 (8374\#). Fax: +1-514-987-8494. E-mail: dstevanovic.econ@ gmail.com
} 


\section{Introduction}

Two facts constitute the background of this paper. First, the U.S. financial system underwent a radical transformation during the last decades. The complexity and the nature of the process of financial intermediation changed substantially. ${ }^{1}$ Figure 1 confirms this well known phenomenon by reporting the evolution of the share of total assets in the U.S. economy held by three major groups of actors: i) the traditional actors (commercial banks, savings institutions and credit unions), ii) the insurance, pension and mutual funds, and iii) the so called "shadow banking system" (Government Sponsored Enterprises (GSE), Assets-backedsecurities issuers, GSE mortgage pools, finance companies, brokers and dealers). ${ }^{2}$ While the share of assets held by the traditional actors declined from about $60 \%$ to roughly $30 \%$ from 1952 to 2010, the share of assets held by the "new" actors increased from almost zero to more than $40 \%$ in 2006 .

Second, a well known result in the economic literature is that in more recent samples, the sensitivity of real variables to monetary policy shocks has declined. A common explanation for this empirical finding is an increase in the effectiveness of monetary policy, as for example proposed by Boivin and Giannoni (2006). Another frequently conjectured (but less studied) hypothesis is that structural changes in the financial sector contributed to the changing nature of the monetary policy transmission mechanism. ${ }^{3}$ Arguably, part of the difficulty in addressing this hypothesis is the lack of a suitable measure of the structural transformation that affected the U.S. financial system. ${ }^{4}$

In this paper, we propose such a measure and study its implications for monetary policy. The Measure of Connectedness is a measure of composition of the assets, namely the share of the credit to the non-financial sectors (households, non-financial firms and government) over the total credit market instruments. The aggregate U.S. Measure of Connectedness

\footnotetext{
${ }^{1}$ See Gorton and Metrik (2012).

${ }^{2}$ See Adrian and Shin (2010), Poznar et al (2012) and references therein for a comprehensive explanation of the concept of Shadow Banking.

${ }^{3}$ A notable exception is Dynan et al (2006), who analyses the impact of monetary policy on real activity before and after relevant regulatory changes.

${ }^{4}$ Contributions in this literature analyze the different responsiveness across different sub-samples of the data.
} 
declines by about $27 \%$ in the period 1952-2009. The increase in the disconnection between the financial sector and the real economy implies a larger interconnectedness within the financial sector. We suggest that this increase in interconnectedness within the financial sector may have dampened the sensitivity of the real economy to monetary shocks. We present a stylized model that illustrates how interbank trading can reduce the sensitivity of lending to the entrepreneur's net worth, thereby dampening the credit channel transmission of monetary policy. We then present some empirical evidence consistent with the predictions of the model.

Importantly, we take here an entirely positive perspective. We are not addressing the question of whether a change in the connection between the financial sector and the real economy is good or bad. ${ }^{5}$

We proceed in three steps. First, we propose as measure of the structural transformation of the financial sector, the extent to which it is connected to the real economy. The Measure of Connectedness is the share of the credit market instruments represented by claims whose direct counterpart belongs to the non-financial sectors (households, non-financial firms and government).We compute the measure of connectedness for each major player in the U.S. financial system for the period 1952-2009, as well as an aggregate measure, using data from the Flows of Funds. The $27 \%$ drop in the aggregate measure over the period 1952-2009 is mostly driven by a composition effect, namely the rising importance of financial institutions that are relatively "disconnected" from the real economy (such as the issuers of AssetsBacked-Securities). ${ }^{6}$

Second, we propose a stylized model to illustrate how inter-bank trading, by increasing the liquidity of investment projects, reduces the sensitivity of lending to monetary policy shocks. In particular, we focus on the balance sheet transmission mechanism of monetary policy. According to this channel, changes in the nominal rate affect the net present value

\footnotetext{
${ }^{5}$ We do think that this is a very interesting question and we will explore it in our future research.

${ }^{6} \mathrm{We}$ also investigate the relation between our measure and the share of finance in U.S. GDP reported by Philippon (2012). While they capture very different concepts, we interestingly find a very high correlation between a series equal to one minus our measure of connectedness and the share of finance in non-defence U.S. value added.
} 
of the borrower's debt obligations and hence his net worth; through various contractual frictions, the change in net worth influences the expected return to lending (for more on this transmission mechanism, see Bernanke and Gertler, 1995). We show that this transmission mechanism is mitigated as investment projects become more liquid. The key to this result is as follows: absent an inter-bank market for investment projects, banks face a tradeoff between investment and liquidity. Consequently, changes in the expected return to investment (for example, through changes in the net worth of the borrower) may change the tradeoff between investment and liquidity, thus affecting the equilibrium amount of investment. In the presence of a liquid inter-bank market for investment projects, there is effectively no tradeoff between investment and liquidity: since all projects have positive net present values (NPV), all projects are implemented, regardless of small changes in their NPV induced by changes in monetary policy.

Finally, we interact our aggregate measure of connectedness with a structural vector auto-regression (VAR) for the U.S. economy, and produce impulse responses to a monetary policy shock conditional on different levels of connection. We check the robustness of our results also using a Factor-Augmented VAR (FAVAR) model. We find that the responses of the real variables to a monetary policy shocks are dampened as the level of the connection between the financial sector and the real economy decreases.

This paper is linked to several strands of the literature. First, it is related to the literature dealing with measurement of financial intermediation and its characteristics. Philippon (2012) provides evidence on the quantitative importance and the cost of financial intermediation in the U.S. in the last 130 years. Greenwood and Scharfstein (2013) analyze the growth of the share of finance on gdp in the U.S. while Philippon and Reshef (2013) analyze the growth of the share of finance for several developed countries. Philippon and Reshef (forthcoming) propose evidence on the evolution of the wages in the financial industry for the period 1909-2006. ${ }^{7}$

Second, this paper is related to the analysis of the relation between financial firms and the real economy. Mesonnier and Stevanovic (2012) use micro-level financial data to construct

\footnotetext{
${ }^{7}$ See also the survey on Financial Intermediation by Gordon and Winton (2003).
} 
an aggregate leverage shock and explore its implication for the real variables. Diebold and Yilmaz $(2012$, 2013) measure the connectedness within financial firms and its contribution to shock transmission. Brunnermeier et al. (2012) analyze the banks' non-interest income and how this affects their contribution to systemic risk. Hahm, Shin and Shin (forthcoming) analyze the non-core liabilities of Korean banks and their implications for financial vulnerability. ${ }^{8}$ We see this paper as complementary to that line of research, since we focus our attention on the composition of assets. Our Measure of Connectedness, in fact, could be interpreted as a measure of the core assets of financial institutions.

Finally, the paper is related to the literature on the monetary policy transmission mechanism. Boivin and Giannoni (2006) report evidence that the effects of monetary policy shocks on real variables are muted in the post 1980 period, and show how this finding can be explained by an increase in the effectiveness of monetary policy. Boivin et al (2011) report FAVAR evidence as well as evidence from DSGE modeling on the change over time of the monetary transmission mechanism. Confirming the results by Boivin and Giannoni (2006), they also find muted responses of real variables to monetary policy innovations in more recent times, and argue that this is mostly accounted for by changes in policy behavior and the effect of these changes on expectations. Adrian and Shin (2011b) consider more in general the role of financial intermediaries in monetary economics. ${ }^{9}$ Closer to our spirit, Dynan et al. (2006) present evidence of the reduced responsiveness of several economic aggregates to shocks, dividing the sample before and after important regulatory changes. We contribute to this literature by providing a measure that can capture the structural transformation underwent by the U.S. financial sector and propose a model that rationalizes the decreased sensitivity of real activity to monetary policy due to this structural transformation.

The paper is organized as follows. In Section 2 we introduce our measure of connectedness between the financial sector and the real economy and document its evolution in the U.S. In Section 3 we outline our stylized theoretical model. In Section 4 we show some empirical

\footnotetext{
${ }^{8}$ See also the discussion of non-core liabilities contained in Adrian and Shin (2011a)

${ }^{9} \mathrm{~A}$ recently proposed complementary channel through which changes in the financial conditions can affect the transmission mechanism of monetary policy is the "risk taking channels", proposed by Borio and Zhu (2012). See also Bruno and Shin (2013).
} 
evidence consistent with the theory. Section 5 concludes with several suggestions for future research.

\section{The measure of connectedness}

Our proposed measure of the connection of a financial sector (or a financial institution) to the real economy is based on the composition of its assets. While the exact formula depends on the type of financial institution analyzed, the Measure of Connectedness is conceptually the share of the credit market instruments represented by claims whose direct counterparts belong to the non-financial sectors (households, non-financial firms and government):

$$
C O N N_{i t}=\frac{C R E D I T_{-} R E A L_{i t}}{C R E D I T_{i t}}
$$

where $C R E D I T_{i t}$ represents the total amount of credit market instruments of a given institution $i$ at time $t$, while $C R E D I T \_R E A L_{i t}$ represents the credit market instruments whose direct counterparts are households (i.e. mortgages and consumer loans), non-financial firms (i.e. commercial loans) or the government (i.e. treasuries). Such a measure can be computed for each player in the U.S. financial system using data from the Flows of Funds.

Probably the most important drawback of using flow of funds data is that we are not able to say much about non-balance sheet items, such as derivatives. Since derivatives are typically used as the main example of the disconnectedness between the financial sector and the real economy, we are aware that we are missing an important piece of information, and we therefore consider our results suggestive of an upper-bound to the level of connectedness. However, an advantage of using flow of funds data is that the measure can be computed for a long time series and hypothetically for different financial systems. Moreover, a conceptually similar measure could be computed also for a single financial institution using balance sheet data.

We stress that we try to measure the share of credit market instruments whose direct counterparts are in the non-financial sector. As many commentators observed, the transfor- 
mation of the financial intermediation process from the "traditional" banking model to the "originate and distribute" model produced a lengthening of the chain linking the ultimate lender to the ultimate borrower (Adrian and Shin, 2011a). This lengthening may have had several consequences, including the erosion of lending standards (Keys et al, 2010), which likely played an important role in the crisis that started in $2007 .^{10}$

In what follows we describe the construction of the measure for each element of the U.S. financial system for the period 1952Q1-2009Q4. ${ }^{11}$ We use data from the release Z1 of March 8, 2012. A Data Appendix contains detail on the composition of the measure for different players within the financial system.

Traditional financial institutions. Traditional financial institutions include Commercial Banks, Savings Institutions and Credit Unions. For commercial banks, at the numerator of our measure we use the sum of Open Market Papers, Treasury Securities, Non-securitized GSE-backed securities, Municipal securities, Non-securitized Corporate Bonds, Bank Loans, Mortgages, Security Credit and Consumer Credit. At the denominator, the total amount of credit market instruments ${ }^{12}$. For Savings Institutions, we use a similar measure. ${ }^{13}$ For Credit Unions, the Flows of Funds table does not distinguish between securitized and notsecuritized bonds. By including all bonds in the numerator of our measure, once again we are conservative and we accept the risk of over-estimating the connectedness with the real economy.

Figure 2 reports the results obtained for the measure of connectedness of the traditional players. All the three indicators are falling over time, from values very close to 1 to values between 0.77 (for the Credit Unions) and 0.84 (Commercial Banks).

\footnotetext{
${ }^{10}$ Moreover, this lengthening of the credit chain might have increase the vulnerability of the system to sudden drop in trust, which arguably was an important element in explaining the freeze of credit markets in the fall of 2008. See Gennaioli, Shleifer, and Vishny (2012) for an example of a model where trust between actors play an important role in the intermediation process.

${ }^{11} \mathrm{~A}$ change in the accounting rule governing the GSE at the beginning of 2010 would introduce a spurious element in our calculations.

${ }^{12}$ Flow of Funds series FL.724.005.005, table L.110

${ }^{13}$ See appendix for details.
} 
Insurances, Mutual Funds and Pension Funds. As in the case of Credit Unions, in the case of Insurances, Pension Funds and Mutual Funds, the tables in the Flow of Funds do not distinguish between asset backed securities and other corporate bonds. Once again, the results need to be interpreted as an upper bound for the connection.

Insurances Companies can be divided into Property-Casualty Insurance Companies and Life Insurance Companies. As for the Mutual Funds, we only consider the two most important categories: Mutual Funds and Money Market Mutual Funds (MMMF). Figure 3 reports the results we obtain. Property and Life Insurances appear to remain fairly connected to the real economy all along the period considered. In contrast, we witness a more pronounced increase in the disconnectedness in the case of mutual funds. Interestingly, the reduction in the connectedness of the MMMF seems to start later, but to have a large drop in the years preceding the crisis, where the MMMF balance sheet were increasingly filled with complex securities like mortgage backed securities (MBS).

Figure 4 shows the evolution of the connectedness over time of Pension Funds. We analyze separately private pension funds, local government pension funds, and federal government pension funds. Here the results are starkly different. While private pension funds appear to have become much more disconnected over time from the real economy (starting from the seventies), the federal government pension funds barely changed, while the local government pension funds started becoming more disconnected during the nineties.

Shadow Banking. We consider the connectedness of Government Sponsored Enterprises (GSEs), Brokers and Dealers, Finance Companies and ABS issuers. Finance companies are fully connected to the real economy, and hence we assign a value of 1 to their measure of connectedness. Figure 5 shows our results for the other actors within shadow banking. Not surprisingly, the Brokers and Dealers appear to be fairly disconnected from the real economy ever since they appear in the eighties. Even more so is the case for the ABS issuers. ${ }^{14}$ More surprising is probably the evolution of the connectedness of the GSEs, who

\footnotetext{
${ }^{14}$ The big drop observed in the series is due to the fact that in the first observation available for ABS issuers in the Flow of Funds (1983q2) the only asset class recorded is trade credit. We consider trade credit as being part of the credit to the real economy, hence the Measure of Connectedness of ABS issuers for that
} 
display a downward trend in the nineties, when they started to invest also in structured financial products.

We exclude from the analysis the Agency and GSE-backed mortgage pools. The reason is to avoid double counting. ${ }^{15}$

Aggregate Measure. In order to have an aggregate picture of the connectedness of the U.S. financial system to the real economy, we take a weighted average of each measure of connectedness, weighting each actor by its time-varying share of credit market instruments:

$$
C O N N_{U S, t}=\sum_{i} \omega_{i, t} * C O N N_{i, t}
$$

where $\omega_{i, t}=\frac{C R E D I T_{i, t}}{C R E D I T_{U S, t}}$ and $i=\{C B, S I, C U, P I, L I, M F, P F, G S E, B R O, F I N, A B S\}$

Figure 6 reports the result. As the figure shows, the aggregate drop in connectedness is of the order of $27 \%$ during the period 1952-2009. It is interesting to notice how the aggregate result we obtain for the measure of connectedness is, to a certain extent, due to a composition effect. Figure 7 shows the shares of credit market instruments held by the different types of financial institutions. Similarly to Figure 1, the shadow banking share increased greatly in the last thirty years, while the share of the traditional players dropped significantly. Figure 8 reports the results on the share of credit market instruments for two particularly relevant players: commercial banks and ABS issuers. As the figure shows, the drop in the share of credit market instruments held by commercial banks is coupled with an important increase in the share of the ABS issuers, which then dropped substantially during the crisis.

It is also interesting to note how our measure of connectedness shows some relation with key moments in the history of the deregulation of the U.S. financial system. The measure has a clear change in trend in the early eighties, when several deregulation acts were promoted in quarter is equal to one.

${ }^{15}$ The Agency and GSE backed securities, in fact, are among the assets that we consider to contribute to the disconnectedness of all the other players in the financial system. An alternative treatment would have been to include this category and assign arbitrarily to this actor a level of connection equal to zero by definition. Once again, we have been conservative and decided to present an upper bound estimate of the level of connection. 
the U.S. ${ }^{16}$. Moreover, the aggregate easure of connectedness seems to accelerate its downward trend for few years, starting in 1999. The Financial Modernization Act, also known as the Gramm-Leach-Bliley Act, passed in 1999, repealed the Glass-Steagall of 1933 and removed the separation between the activities of commercial banking and investment banking, thus spurring a wave of mergers and acquisitions in the U.S. financial sector and leading to a transformation of the business model in several U.S. financial institutions.

Finally, it is important to stress again that here we take an entirely positive perspective, and we are not able to say anything about the welfare implications of the increased disconnectedness between the financial sector and the real economy.

Measure of connectedness and the share of finance in GDP. It is instructive to investigate the relation between our measure of connectedness and the share of finance in GDP, constructed by Philippon (2012). In Figure 9, we report both a series equal to one minus our measure of connectedness, which is a measure of disconnection between the financial sector and the real economy, and the share of finance in non-defence value added ${ }^{17}$.

While the two series are conceptually different, they are interestingly highly correlated. ${ }^{18}$ Our measure of connectedness is a way of representing the structural transformation that affected the U.S. financial system in the last fifty years. Philippon (2012) measures the share of finance in U.S. GDP. One could conjecture that the structural transformation of the U.S. financial sector captured by our measure might have contributed to a reallocation of resources towards finance, thus implying a greater share of finance in GDP. However other factors, such as a sector-specific technological change or the increasing trend toward financial globalization, might also help explaining Philippon's findings. ${ }^{19}$

\footnotetext{
${ }^{16}$ For Instance the Depository Institutions Deregulation and Monetary Control Act in 1980 and the GarnSt Germain Depository Institutions Act, in 1982.

${ }^{17}$ While Philippon's data are at annual frequency, we interpolated them to transform them into a quarterly series.

${ }^{18}$ The correlation between the two series is 0.98 .

${ }^{19}$ Another recent explanation of Philippon's results can be found in Gennaioli, Shleifer and Vishny (2013), who propose a Solow-type growth model augmented with a financial intermediation process featuring a role for trust. In their model, the share of finance over GDP grows over time due to the role of financial intermediation as a tool for wealth management in an environment where the ratio of wealth to GDP grows as the economy approaches its steady state.
} 
Since this paper focuses mainly on the implications for monetary policy of the structural transformation that affected the U.S. financial system, we focus in what follows on our measure of connectedness, without taking a strong stance on its contribution to the increase in the share of finance in GDP.

\section{Connectedness and monetary policy: theory}

We present a stylized model that captures a possible relationship between the connectedness of the financial sector and the sensitivity of real activity to monetary policy. We focus on the credit channel of transmission of monetary policy, and show how a financial sector more disconnected from the real economy implies a lower sensitivity of lending to interest rate changes.

The basic environment is similar to Diamond and Dybvig (1983) and Allen and Gale (2000), with some ex-ante uncertainty. There are three periods, $t=0,1,2$. At time 0 , a continuum of banks are endowed with 1 unit of deposits (deposits here are time 0 goods). At that time, a fraction $q_{0}$ of banks are also endowed with an investment opportunity: an investment of $I$ units of deposits at $t=0$ (where $0 \leq I \leq 1$ ) yields a return of $A I^{\alpha}$ at $t=2$. An investment opportunity can be seen as a request of a loan by an entrepreneur. The parameter $A$ is the recoverable part of output, which in principle changes with the entrepreneur's net worth. In the background, we can think of an entrepreneur with some initial debt obligations, and some net worth $(N)$. The parameter $A$ depends on his net worth $N$ and therefore is decreasing with the NPV of his debt obligations (decreasing in $r$, the interest rate set by the monetary authority). ${ }^{20}$ We assume that any enforceability problems are already summarized in $A$, the recoverable part of output. The banks observe the realization of $A$ before making their lending decision.

In the background, there is a transmission mechanism of monetary policy: $A$ is increasing in the net worth of the entrepreneur $N$, and $N$ is decreasing in $r$. We thus focus on the

\footnotetext{
${ }^{20}$ We do not take a strong stance on the reason why $A$ might depend on the net worth of the entrepreneur. A possible interpretation is that the entrepreneur puts more effort if his net worth is higher. Formally, we are assuming a function $A(N(r))$ with $N^{\prime}(r)<0$ and $A^{\prime}>0$.
} 
balance sheet channel, as described by Bernanke and Gertler (1995).

All banks - those who receive an investment opportunity and those who don't - have access to a storage technology, that transforms one unit of output at time $t$ to one unit of output in time $t+1$. For banks without an investment opportunity, this is the only technology. Banks with an investment opportunity choose between saving in storage and investing.

The bank's time 0 objective function is:

$$
E\left(\theta c_{1}+c_{2}\right)
$$

Where $c_{1}$ is consumption goods at time 1 and $c_{2}$ is consumption goods at time 2 . The parameter $\theta$ is a liquidity shock, that takes value $\bar{\theta}>1$ with probability $q$ and value $\theta=1$ with probability $1-q$. A realization of $\theta=\bar{\theta}>1$ can be thought of as whatever might induce banks to prefer liquidity at time 1 as opposed to time 2 .

We first solve the model under the assumption that there is no interbank market. Given our definition of connectedness, this is equivalent to a situation of full connectedness, as the banks only deal with entrepreneurs. We will then allow for the possibility of an interbank market that can be thought of as a partially connected environment. It is useful to keep in mind, given our definitions, that a greater disconnectedness between the financial sector and the real economy implies a greater interconnectedness within the financial sector.

The fully connected environment. Absent trade between banks, banks choose the amount of storage and investment to maximize their objective function. For banks that do not have an investment opportunity, the problem is trivial: they will store all deposits; if, at period 1 , they find that $\theta=\bar{\theta}$, they will consume all goods at $t=1$. Otherwise, they are indifferent between time 1 and time 2 consumption.

For banks with an investment opportunity, the bank's problem can be written as:

$$
\max _{I \in[0,1]} E\left(\theta c_{1}+c_{2}\right)
$$


s.t.

$$
\begin{gathered}
c_{1}=1-I \\
c_{2}=A I^{\alpha}
\end{gathered}
$$

Note that, if $\theta=\bar{\theta}$, the bank strictly prefers to consume its storage rather than to store it for period $t=2$. If $\theta=1$, the bank is indifferent between the two options, so we can assume without loss of generality that it consumes all stored goods at time $t=1$. Substituting in the constraints, the problem amounts to:

$$
\max _{I \in[0,1]} E\left(\theta(1-I)+A I^{\alpha}\right)
$$

Assuming an interior solution, the first order condition is:

$$
E(\theta)=\alpha A I^{\alpha-1} \Rightarrow I^{1-\alpha}=\frac{\alpha}{E(\theta)} A \Rightarrow I=\left(\frac{\alpha}{E(\theta)} A\right)^{\frac{1}{1-\alpha}}
$$

Note that equation (7) admits an interior solution only if $E(\theta)>\alpha A$. In other words, if the expected valuation of liquidity at $t=1$ is sufficiently high, it is optimal for the bank to store some deposits. Assuming that this parametric restriction is satisfied, the interior solution is increasing in $A$, so there is some transmission of monetary policy (that changes $A(N)$ ). In contrast, at the corner solution small changes in $A$ (or in $N$, or in $r$ ) would not change the bank's investment decision, and there would be no sensitivity to monetary shocks.

Formally, we define the sensitivity of real activity with respect to monetary policy in this model to be the semi-elasticity of aggregate investment to interest rate changes. We decompose this semi-elasticity as follows:

$$
\frac{\partial \ln I}{\partial r}=\frac{\partial \ln I}{\partial A} \frac{\partial A}{\partial N} \frac{\partial N}{\partial r}
$$

We assume the second term to be positive and the third term to be negative. Then, from equation (8), we get: 


$$
\frac{\partial \ln \left(I_{c}^{A G G}\right)}{\partial A}=\frac{\frac{\partial}{\partial A}\left(\frac{\alpha}{E(\theta)} A\right)^{\frac{1}{1-\alpha}}}{\left(\frac{\alpha}{E(\theta)} A\right)^{\frac{1}{1-\alpha}}}
$$

where $I_{c}^{A G G}$ is the aggregate investment in the fully connected environment.

The partially connected environment. Assume next that a fraction $\lambda$ of investment opportunities are tradable at time $t=1$. This is a very reduced form way of introducing securitization in the model. ${ }^{21}$ The securitization is the process through which an illiquid asset can be sold by the bank to a special investment vehicle (SIV). The SIV transform the illiquid asset into securities, by issuing bonds with stratified risk profiles. The banks, at time $t=0$, know whether their investment opportunity (if any) is tradable (liquid)or not.

If there are enough banks with $\theta=1$ who hold stored goods, the price of time 2 goods in terms of time 1 goods is $1 .^{22}$ In this case, banks holding tradable projects who realize $\theta=\bar{\theta}$ can sell their investments at time $t=1$ at no loss. We treat $\lambda$ as a proxy for the extent of the possible interconnectedness within the financial system, and thus as a measure of the disconnectedness between the financial sector and the real economy. The maximization problem of a bank that has a non-tradable project is the same as in the fully connected environment. For banks with a tradable project, the ability to sell the project at $t=1$ increases the returns to investment. Since banks always weakly prefer to consume at time $t=1$, their maximization problem can be written as if they only consume at time 1 :

$$
\max _{I \in[0,1]} E\left(\theta\left(1-I+A I^{\alpha}\right)\right)
$$

\footnotetext{
${ }^{21}$ Hobijn and Ravenna (2010) analyze the influence of securitization on monetary policy in the context of a DSGE model. See Moran and Meh (2013) for a DSGE model featuring a shadow banking sector.

${ }^{22}$ For this to be the case, we need to assume enough "liquid demand" for these assets. Formally, a sufficient condition for this to hold for every $\lambda$ is $\left(1-q_{0}\right)(1-q)>q_{0} q A$. The left hand side is the amount of storage goods in the hand of $\theta=1$ banks who did not receive an investment opportunity at time 0 . These banks hold storage goods, and are indifferent between time 1 goods and time 2 goods. The right hand side is the value of investment opportunities in the hand of banks who had an investment opportunity, and received a liquidity shock that made it optimal for them to sell at $t=1$ (given $I=1$, each project promises $A I^{\alpha}=A$ units of time 2 goods). We assume this is the case, in order to capture the large demand for securitized assets prevailing in the financial markets, especially before 2007.
} 
The FOC with respect to $I$ is:

$$
\alpha A I^{\alpha-1}=1 \Rightarrow I^{1-\alpha}=\alpha A
$$

For $\alpha A>1$, there is no interior solution. We will assume that this is the case. To summarize, we are making the following parametric restriction:

$$
E(\theta)>\alpha A>1
$$

Given this assumption, banks with tradable investment projects have a corner solution, in which they invest the maximum amount $I=1$. Intuitively, there is no liquidity advantage to storage if the investment project is tradable. Given a corner solution $I=1$, the amount of investment does not respond to small changes in $A$ or in $r$ - investment in these banks is unresponsive to monetary policy.

At the aggregate level, note that investment is now given by:

$$
I_{d}^{A G G}=\lambda+(1-\lambda)\left(\frac{\alpha}{E(\theta)} A\right)^{\frac{1}{1-\alpha}}
$$

The sensitivity to monetary policy is given by:

$$
\frac{\partial \ln \left(I_{d}^{A G G}\right)}{\partial A}=\frac{(1-\lambda) \frac{\partial}{\partial A}\left(\frac{\alpha}{E(\theta)} A\right)^{\frac{1}{1-\alpha}}}{\lambda+(1-\lambda)\left(\frac{\alpha}{E(\theta)} A\right)^{\frac{1}{1-\alpha}}}
$$

Note that $\lambda=0$ corresponds to the fully connected case. The absolute value of the above expression is decreasing in $\lambda$. To see this, note that the absolute value of this expression is of the form $\frac{(1-\lambda) a}{(1-\lambda) b+\lambda}$ where $a>0$ and $b<1$. The derivative with respect to $\lambda$ is:

$$
\frac{-a((1-\lambda) b+\lambda)-(1-b)(1-\lambda) a}{((1-\lambda) b+\lambda)^{2}}<0
$$

This result implies that that the sensitivity of aggregate investment to monetary policy is increasing in connectedness. Note that, in this model, our measure of connectedness 
corresponds to the share of claims at $t=1$ for which the direct counterpart is investment projects. The "disconnected" part is claims held by banks on investment projects initiated by other banks. ${ }^{23}$ The equilibrium level of connectedness is given by:

$$
\operatorname{CONN}(\lambda)=\frac{I(\lambda)}{\lambda q_{0} q+I(\lambda)}
$$

It is easy to verify that this expression is decreasing in $\lambda$.

Moreover, from equation (12), the aggregate amount of lending is increasing in $\lambda\left(\frac{\partial I_{d}^{A G G}}{\partial \lambda}>\right.$ $0)$. Intuitively, securitization makes lenders less careful about investing in illiquid assets if they can be sold in case of need at time $t=1$.

Altunbas, Gambacorta and Marquez-Ibanez (2009), using detailed information on securitization activities for a sample of European banks, find both that securitization shelters banks' loans from the effect of monetary policy and that it strengthens the capacity of banks to supply loans. Both results hold in the simple model we presented in this section.

\section{Connectedness and monetary policy: evidence}

This section presents some time series evidence to explore how connectedness affects the responses of economic variables to monetary policy shocks. We follow both a structural VAR (SVAR) approach as well as a factor-augmented VAR (FAVAR).

SVAR. We adapt the approach of Boivin and Giannoni (2006) by including our measure of connectedness as an exogenous variable. ${ }^{24}$ The model can be written as follows:

$$
Y_{t}=\Phi(L) Y_{t-1}+\beta C O N N_{t-1} Y_{t-1}+e_{t}
$$

\footnotetext{
${ }^{23}$ Instead of "purchasing" the investment projects directly, we can think of the interbank market more realistically as a loan market, in which banks with tradable investment projects borrow against $t=2$ investment income. Here, "tradable" has the interpretation of "collateralizable".

${ }^{24}$ While arguably also the connection might be an endogenous variable, the result obtained in figure 6 indicates how the movements in the connection are long-run smooth movements, and thus we believe it can be considered an exogenous when using business cycle frequency data. In addition, the connection is included with lag one.
} 
where $Y_{t}$ is a $K \times 1$ vector of endogenous variable, $\Phi(L)$ is a matrix polynomial of order $p$ and $C O N N_{t-1}$ is exogenous. The reduced form errors, $e_{t}$, are assumed to be linear combinations of structural shocks, $\varepsilon_{t}$ :

$$
e_{t}=H \varepsilon_{t}
$$

with $E\left(\varepsilon_{t} \varepsilon_{t}^{\prime}\right)=\Sigma$, a diagonal matrix.

It is easy to see that the impulse responses to any shock in $\varepsilon_{t}$ will depend on $C O N N_{t-1}$. Without loss of generality, assume $p=2$ and develop $\Phi(L)$ :

$$
\begin{aligned}
Y_{t} & =\Phi_{1} Y_{t-1}+\Phi_{2} Y_{t-2}+\beta C O N N_{t-1} Y_{t-1}+e_{t} \\
& =\left(\Phi_{1}+\beta C O N N_{t-1}\right) Y_{t-1}+\Phi_{2} Y_{t-2}+e_{t} \\
& =\Phi_{1, t-1} Y_{t-1}+\Phi_{2} Y_{t-2}+e_{t},
\end{aligned}
$$

where $\Phi_{1, t-1}=\left(\Phi_{1}+\beta C O N N_{t-1}\right)$. Hence, the impulse response functions (IRFs) are obtained for any level of $C O N N_{t-1}$ by inverting the previous expression:

$$
Y_{t}=\left[\mathbf{I}-\Phi_{1, t-1} L-\Phi_{2} L^{2}\right]^{-1} H \varepsilon_{t}
$$

In practice, the coefficients matrices $\Phi(L)$ and $\beta$ are estimated by OLS regression on (18), and $H$ is deduced by imposing enough identification restrictions. The IRFs are then easily computed using (19). The confidence bands can be constructed using a parametric bootstrap. ${ }^{25}$ Following Boivin and Giannoni (2006), $Y_{t}$ contains the deviation of the natural

${ }^{25}$ We use the following procedure:

1. Shuffle the time dimension of OLS residuals $\hat{e}_{t}$ and get bootstrap innovations $e_{t}^{*}$

2. Using $\left[Y_{1}, \ldots, Y_{p}\right]$ as initial values and $C O N N_{t-1}$, get the bootstrap endogenous variables from

$$
Y_{t}^{*}=\hat{\Phi}(L) Y_{t-1}^{*}+\hat{\beta} C O N N_{t-1} Y_{t-1}^{*}+e_{t}^{*}
$$

3. Impose the identification restrictions to get $H$ and calculate impulse responses. 
logarithm of quarterly real GDP (GDPQ) from a linear deterministic trend, the annualized rate of change in the quarterly GDP deflator (GDPD), the natural logarithm of the quarterly average of the monthly spot market commodity price index (PSCCOM) and the quarterly average of the Federal Funds Rate (FFR). The exogenous variable $C O N N_{t-1}$ contains our aggregate Measure of Connectedness. The data ranges from 1959Q1 to 2009Q1.

Four lags are included in the VAR. The identification of structural shocks is achieved by the following recursive ordering: [ PSCCOM, GDPQ, GDPD, FFR ]. Hence, the unexpected monetary policy shock is ordered last in $\varepsilon_{t}$. The rotation matrix $H$ is obtained using Choleski decomposition of the covariance matrix of $\hat{e}_{t}$. The $95 \%$ confidence intervals are computed using 1000 bootstrap replications.

In Figure (10), we compare the impulse responses of elements in $Y_{t}$ to an adverse monetary policy shock when the Measure of Connectedness is high and low, respectively $C O N N=0.98$ and $C O N N=0.82$. These are the average values of our connectedness measures for the periods 1959Q1-1983Q4 and 1984Q1-2009Q1. The impulse response with confidence bands for each level of connectedness are presented in Figures (11) and (12).

As we can see from Figure (10), at the level of connection of 0.98 the adverse monetary shock generates a decrease in output, which exhibit a hump-shaped response. The price level decreases too, but only after few quarters (the well known price puzzle phenomenon). When we consider a level of connection of 0.82 , instead, we see that the response of the GDP to the same monetary policy shock is now not statistically different from zero. Also the response of the quarterly GDP deflator and the spot market commodity price index are muted at the lower level of connection. Interestingly, there is no evidence of price puzzle in that case.

In order to assess whether the difference in the impulse response we obtained under different levels of connection is statistically significant, we plot the difference in figure (13), and we include confidence intervals at $90 \%$ significance level. As the figure shows, the impulse responses of GDP and GDP deflator are statistically different under the two scenarios, while the impulse responses of the commodity price index and the federal funds rate are not statistically significantly different. 
The results reported in Figure (13) are robust to the inclusion of a time trend in the model, as well as to a different specification of the lag structure. ${ }^{26}$

FAVAR. We conduct a more refined exercise inspired by the model from Bernanke et al.(2005). In contrast to standard structural VAR models, factor models have a number of advantages: i) they allow considering large amounts of information potentially observed by agents, and thus minimize the risk of omitted variable bias; ii) they are not sensitive to the choice of a specific data series, which may be arbitrary; iii) they are less likely to be subject to non-fundamentalness issues raised by Forni et al. (2009) ${ }^{27}$; and iv) they allow us to compute the response of a larger set of variables of interest to identified shocks.

As in the case of SVAR, we introduce our measure of connectedness through interaction terms, in order to obtain impulse response functions that are conditional on a certain level of connectedness. Formally, we consider the following static factor model with latent and observed factors:

$$
\begin{aligned}
X_{t} & =\Lambda^{F} F_{t}+\Lambda^{R} R_{t}+u_{t} \\
{\left[\begin{array}{c}
F_{t} \\
R_{t}
\end{array}\right] } & =\Phi(L)\left[\begin{array}{c}
F_{t-1} \\
R_{t-1}
\end{array}\right]+\beta C O N N_{t-1}\left[\begin{array}{c}
F_{t-1} \\
R_{t-1}
\end{array}\right]+e_{t}
\end{aligned}
$$

where $F_{t}$ is vector of $K$ latent factors and $R_{t}$ is the observed factor. In our case, $R_{t}$ is the the Federal Funds Rate, since the objective here is to identify the monetary policy shock. $X_{t}$ contains $N$ macroeconomic and financial indicators organized into a block of 'slow-moving' variables that are largely predetermined to monetary policy, and another consisting of 'fast moving' variables that are sensitive to the FED's rule. The idiosyncratic errors are assumed to be serially uncorrelated.

In our application, $X_{t}$ contains $N=108$ quarterly time series from $\mathrm{Ng}$ and Stevanovic

\footnotetext{
${ }^{26} \mathrm{We}$ omitted the results here, they are available upon request.

${ }^{27}$ If the shocks in the VAR model are fundamental, then the dynamic effects implied by the moving average representation can have a meaningful interpretation, i.e. the structural shocks can be recovered from current and past values of observable series. Forni et al. (2009) argue that while non-fundamentalness is generic of small scale models, it is highly unlikely to arise in large dimensional dynamic factor models.
} 
(2012), that run from 1959Q1 to 2009Q1. Data include both macroeconomic variables such as gdp, employment, investment, hours worked, inflation rate as well as financial variables such as credit spreads, loans etc. ${ }^{28}$ The data have been transformed to induce stationarity and are standardized prior to estimation. The $I C_{p 2}$ information criteria from Bai and $\mathrm{Ng}$ (2002) suggests $K=3$ latent factors. The lag order of $\Phi(L)$ is set to 4 .

The estimation and identification of structural shocks consist of several steps. First, one must impose $R_{t}$ as an observed factor when estimating $F_{t}$. Let $\hat{C}\left(F_{t}, R_{t}\right)$ be the $K$ principal components of $X_{t}$. Let $X_{t}^{S}$ be $N_{S}$ 'slow' moving variables, and let the $K$ principal components of $X_{t}^{S}$ be $C^{\star}\left(F_{t}\right)$. The estimate of latent factors is $\hat{F}_{t}=\hat{C}\left(F_{t}, R_{t}\right)-\hat{b}_{R} R_{t}$ where $\hat{b}_{R}$ is obtained by least squares estimation of the regression

$$
\hat{C}\left(F_{t}, R_{t}\right)=b_{C} C^{\star}\left(F_{t}\right)+b_{R} R_{t}+u_{t}
$$

The estimation of the loadings is now straightforward by regressing $X_{t}$ on $\hat{F}_{t}$ and $R_{t}: \hat{\Lambda^{F}}$ and $\hat{\Lambda^{R}}$.

Second, using $\hat{F}_{t}$, we estimate $(21)$ as in the case of SVAR model. Since $\hat{F}_{t}$ can be correlated with $R_{t}$, we identify the monetary policy by ordering $R_{t}$ last. Finally, we invert (21) to obtain factors' impulse responses, and multiply them by factor loadings to get the IRFs of any element in $X_{t}$. While all the impulse responses are available upon request, we present here only a subset of them.

As before, we compare the impulse responses to an adverse monetary policy shock when the connectedness is high and low, respectively $C O N N=0.98$ and $C O N N=0.82$. In figure (14) we report the responses of output, investment and employment to an identified monetary policy shock. In all three cases, the responses of real variables to a monetary innovation are muted at lower levels of connectedness. In order to test whether these differences are statistically significant, we compute the difference between the impulse responses and we compute via bootstrap a $90 \%$ confidence internal. In figure (15) we report the results. The impulse responses of GDP, Investment and Employment are statistically different, at least

\footnotetext{
${ }^{28}$ The complete description of the data and their transformation is presented in the appendix.
} 
in the first few quarters.

In figure (16) we report the results for CPI inflation, bank lending and loans and leases. Interestingly, also the response of bank lending and loans and lease are muted in the case of

a lower connection between the financial sector and the real economy. This is precisely the mechanism that we highlighted in the previous section. As before, we check the statistical significance of these results by plotting the difference of the impulse responses and the associated confidence intervals. We show the results in figure (17).

We conclude that the inclusion of our measure of connectedness into a SVAR or a FAVAR for the U.S. economy generates statistically different responses of real variables to monetary policy innovations.

\section{Conclusions}

This paper documents a declining trend in the share of financial claims whose direct counterpart is in the non-financial sector. The financial sector's increased ability to buffer idiosyncratic liquidity shocks may have contributed to an increase in investment, and a decrease in the sensitivity of investment to fundamentals such as the borrower's net worth. In this paper, we illustrate how this may have contributed to the dampening of the responsiveness to monetary policy. However, the implications of this structural change in the financial system may have had implications far beyond this. We outline here several potential avenues for future research that make use of the measure of connectedness.

First, it would be interesting to develop a quantitative macroeconomic model embedding the concept of connection explored in this paper. This could also be used to evaluate the relative importance of the policy behavior and the disconnectedness in explaining the muted responses of monetary policy innovations on economic variables found using more recent samples.

Second, it would be interesting to explore whether the connection between the financial sector and the real economy affects other dimensions of the macro economy (for example, the availability of credit to firms or the vulnerability to financial crisis). 
Third, it may be insightful to analyze the dynamics of the connection between the financial sector and the real economy for additional countries, and study how connection was related to performance during the Great Recession. In this sense, it would be interesting also to address "normative" questions, such as the effects of connectedness on welfare.

Finally, and especially for policy purposes, it would be important to go beyond the aggregate perspective we take in this paper and use balance sheet data on single financial institutions to analyze the impact of their connection with the real economy on a range of performance measures. This could also help improve the regulation and monitoring of financial institutions. We plan to pursue these avenues in our future research. 


\section{A Appendix}

\section{A.1 Measure of Connectedness}

The following table report the exact composition of the numerator of Measure of Connectedness for each U.S. financial actor. At the denominator, we always used the total credit market instruments.

\begin{tabular}{ll}
\hline U.S. Financial Actor & $C R E D I T \_R E A L$ \\
\hline Commercial Banks & Open Market Papers, Treasury Securities, Non-securitized GSE-backed securities, Municipal securities \\
& Non-securitized Corporate Bonds, Bank Loans, Mortgages, Security Credit and Consumer Credit \\
Savings Institutions & Open Market Papers, Treasury Securities, Non-securitized GSE-backed securities, Municipal securities, \\
& Non-securitized Corporate Bonds, Mortgages, and Consumer Credit \\
Credit Unions & Open Market Papers, Treasury Securities, Corporate Bonds, Home Mortgages, and Consumer Credit \\
\hline Property Ins Comp & Open Market Papers, Treasury Securities, Municipal Securities, Mortgages and Corporate Bonds \\
Life Ins Comp & Open Market Papers, Treasury Securities, Municipal Securities, Mortgages and Corporate Bonds \\
\hline Mutual Funds & Open Market Papers, Treasury Securities, Municipal Securities, Corporate Bonds and other loans \\
MMMF & Open Market Papers, Treasury Securities, Municipal Securities, Corporate Bonds and other loans \\
Private Pension funds & Open Market Papers, Treasury Securities, Municipal Securities, Corporate Bonds and other loans \\
Local Govt pension funds & Open Market Papers, Treasury Securities, Municipal Securities, Corporate Bonds and other loans \\
Federal Govt pension funds & Open Market Papers, Treasury Securities, Municipal Securities, Corporate Bonds and other loans \\
\hline GSEs & Open Market Papers, Treasury Securities, Municipal Securities, Corporate Bonds and Mortgages \\
Brokers and Dealers & Open Market Papers, Municipal Securities and Corporate Bonds \\
ABS issuers & Treasury Securities, Consumer Credit and Trade Credit \\
\hline
\end{tabular}

\section{A.2 Data Used in the FAVAR}

The transformation codes are: 1 no transformation; 2 first difference; 4 logarithm; 5 first difference of logarithm; 0 variable not used in the estimation (only used for transforming other variables). A* indicates a series that is deflated with the GDP deflator (series \#89).

$\begin{array}{ll}\text { No. } & \text { Series Code } \\ 1 & \text { DRIINTL:GDPRC@US.Q } \\ 2 & \text { USCEN:GDPGDR.Q } \\ 3 & \text { USCEN:GDPSVR.Q } \\ 4 & \text { USCEN:GDPSR.Q } \\ 5 & \text { BASIC:IPN11.M } \\ 6 & \text { BASIC:IPN300.M } \\ 7 & \text { BASIC:IPN12.M } \\ 8 & \text { BASIC:IPN13.M } \\ 9 & \text { BASIC:IPN18.M } \\ 10 & \text { BASIC:IPN25.M } \\ 11 & \text { BASIC:IPN32.M } \\ 12 & \text { BASIC:IPN34.M } \\ 13 & \text { BASIC:IPN38.M } \\ 14 & \text { BASIC:IPN10.M } \\ 15 & \text { USCEN:UTLB00004.M } \\ 16 & \text { BASIC:PMI.M }\end{array}$

$\begin{array}{ll}\text { T-Code } & \text { Series Description } \\ 5 & \text { NIA REAL GROSS DOMESTIC PRODUCT (CHAINED-2000), SA - U.S. } \\ 5 & \text { REAL GDP-GDS,BILLIONS OF CH (2000) \$,SAAR-US } \\ 5 & \text { REAL GDP-SVC,BILLIONS OF CH (2000) \$,SAAR-US } \\ 5 & \text { REAL GDP-STRUC,BILLIONS OF CH (2000) \$,SAAR-US } \\ 5 & \text { INDUSTRIAL PRODUCTION INDEX - PRODUCTS, TOTAL } \\ 5 & \text { INDUSTRIAL PRODUCTION INDEX - FINAL PRODUCTS } \\ 5 & \text { INDUSTRIAL PRODUCTION INDEX - CONSUMER GOODS } \\ 5 & \text { INDUSTRIAL PRODUCTION INDEX - DURABLE CONSUMER GOODS } \\ 5 & \text { INDUSTRIAL PRODUCTION INDEX - NONDURABLE CONSUMER GOODS } \\ 5 & \text { INDUSTRIAL PRODUCTION INDEX - BUSINESS EQUIPMENT } \\ 5 & \text { INDUSTRIAL PRODUCTION INDEX - MATERIALS } \\ 5 & \text { INDUSTRIAL PRODUCTION INDEX - DURABLE GOODS MATERIALS } \\ 5 & \text { INDUSTRIAL PRODUCTION INDEX - NONDURABLE GOODS MATERIALS } \\ 5 & \text { INDUSTRIAL PRODUCTION INDEX - TOTAL INDEX } \\ 1 & \text { CAPACITY UTILIZ-MFG,SA-US } \\ 1 & \text { PURCHASING MANAGERS' INDEX (SA) }\end{array}$




\begin{tabular}{|c|c|c|}
\hline 17 & BASIC:PMP.M & 1 \\
\hline 18 & DRIINTL:WS@US.Q & $5^{*}$ \\
\hline 19 & USCEN:YPR.M & 5 \\
\hline 20 & USCEN:YP@V00C.M & 5 \\
\hline 21 & USCEN:AHPMF.M & $5^{*}$ \\
\hline 22 & USCEN:AHPCON.M & $5^{*}$ \\
\hline 23 & USCEN:HPMF.M & 5 \\
\hline 24 & USCEN:HOPMD.M & 5 \\
\hline 25 & BASIC:LHEL.M & 5 \\
\hline 26 & BASIC:LHELX.M & 1 \\
\hline 27 & BASIC:LHEM.M & 5 \\
\hline 28 & BASIC:LHNAG.M & 5 \\
\hline 29 & BASIC:LHUR.M & 1 \\
\hline 30 & BASIC:LHU680.M & 1 \\
\hline 31 & BASIC:LHU5.M & 5 \\
\hline 32 & BASIC:LHU14.M & 5 \\
\hline 33 & BASIC:LHU15.M & 5 \\
\hline 34 & BASIC:LHU26.M & 5 \\
\hline 35 & BASIC:CES001.M & 5 \\
\hline 36 & BASIC:CES002.M & 5 \\
\hline 37 & BASIC:CES003.M & 5 \\
\hline 38 & USCEN:CR.Q & 5 \\
\hline 39 & USCEN:JQCDR.Q & 5 \\
\hline 40 & USCEN:JQCNR.Q & 5 \\
\hline 41 & USCEN:JQCSVR.Q & 5 \\
\hline 42 & USCEN:JQCXFAER.Q & 5 \\
\hline 43 & DRIINTL:CGRCUS.Q & 5 \\
\hline 44 & USCEN:I.Q & $5^{*}$ \\
\hline 45 & USCEN:IF.Q & $5^{*}$ \\
\hline 46 & USCEN:IFNRE.Q & $5^{*}$ \\
\hline 47 & USCEN:IFRES.Q & $5^{*}$ \\
\hline 48 & USCEN:IFRE.Q & $5 *$ \\
\hline 49 & USCEN:II.Q & 1 \\
\hline 50 & USCEN:IIF.Q & 1 \\
\hline 51 & BASIC:HSFR.M & 4 \\
\hline 52 & BASIC:HMOB.M & 4 \\
\hline 53 & BASIC:PMNV.M & 1 \\
\hline 54 & BASIC:PMNO.M & 1 \\
\hline 55 & BASIC:PMDEL.M & 1 \\
\hline 56 & BASIC:MOCMQ.M & 5 \\
\hline 57 & BASIC:MSONDQ.M & 5 \\
\hline 58 & USCEN:M.Q & 5 \\
\hline 59 & USCEN:X.Q & 5 \\
\hline 60 & BASIC:FSPCOM.M & 5 \\
\hline 61 & BASIC:FSPIN.M & 5 \\
\hline 62 & BASIC:FSDXP.M & 1 \\
\hline 63 & BASIC:FSPXE.M & 1 \\
\hline 64 & BASIC:EXRUK.M & 5 \\
\hline 65 & BASIC:EXRCAN.M & 5 \\
\hline 66 & BASIC:FYGM3.M & 1 \\
\hline 67 & BASIC:FYGM6.M & 1 \\
\hline 68 & BASIC:FYGT1.M & 1 \\
\hline 69 & BASIC:FYGT5.M & 1 \\
\hline 70 & BASIC:FYGT10.M & 1 \\
\hline 71 & BASIC:FYAAAC.M & 1 \\
\hline 72 & BASIC:FYBAAC.M & 1 \\
\hline 73 & FYGM6-FYFF & 1 \\
\hline 74 & FYGM3-FYFF & 1 \\
\hline
\end{tabular}

NAPM PRODUCTION INDEX (PERCENT)

NIA NOMINAL TOTAL COMPENSATION OF EMPLOYEES, SA - U.S.

PERS INCOME CH 2000 \$,SA-US

PERS INCOME LESS TRSF PMT CH 2000 \$,SA-US

AHE,PROD WORKERS: MFG,SA-US

AHE,PROD WORKERS: CONSTR,SA-US

AWH,PROD WORKERS: MFG,SA-US

AVG WEEKLY OT,PROD WORKERS: DUR,SA-US

INDEX OF HELP-WANTED ADVERTISING IN NEWSPAPERS (1967=100;SA)

EMPLOYMENT: RATIO; HELP-WANTED ADS:NO. UNEMPLOYED CLF

CIVILIAN LABOR FORCE: EMPLOYED, TOTAL (THOUS.,SA)

CIVILIAN LABOR FORCE: EMPLOYED, NONAGRIC.INDUSTRIES (THOUS.,SA)

UNEMPLOYMENT RATE: ALL WORKERS, 16 YEARS \& OVER (\%,SA)

UNEMPLOY.BY DURATION: AVERAGE(MEAN)DURATION IN WEEKS (SA)

UNEMPLOY.BY DURATION: PERSONS UNEMPL.LESS THAN 5 WKS (THOUS.,SA)

UNEMPLOY.BY DURATION: PERSONS UNEMPL.5 TO 14 WKS (THOUS.,SA)

UNEMPLOY.BY DURATION: PERSONS UNEMPL.15 WKS + (THOUS.,SA)

UNEMPLOY.BY DURATION: PERSONS UNEMPL.15 TO 26 WKS (THOUS.,SA)

EMPLOYEES, NONFARM - TOTAL NONFARM

EMPLOYEES, NONFARM - TOTAL PRIVATE

EMPLOYEES, NONFARM - GOODS-PRODUCING

REAL PCE,BILLIONS OF CH (2000) \$,SAAR-US

REAL PCE-DUR,QTY INDEX $(2000=100)$,SA,SA-US

REAL PCE-NDUR,QTY INDEX $(2000=100)$,SA,SA-US

REAL PCE-SVC,QTY INDEX $(2000=100)$, SA,SA-US

REAL PCE EX FOOD\&ENERGY,QTY INDEX $(2000=100)$,SAAR-US

REAL GOVERNMENT CONS. EXPEND.\& GROSS INVESTMENT (CHAINED-2000), SA - U.S.

GROSS PRIV DOM INVEST,BILLIONS OF \$,SAAR-US

GROSS PRIV DOM INVEST-FIXED,BILLIONS OF \$,SAAR-US

GROSS PRIV DOM INVEST-FIXED NONRES,BILLIONS OF \$,SAAR-US

PRIV FIXED INVEST-RES-STRUC,BILLIONS OF \$,SAAR-US

GROSS PRIV DOM INVEST-FIXED RES,BILLIONS OF \$,SAAR-US

GROSS PRIV DOM INVEST-CH IN PRIV INVENT,BILLIONS OF \$,SAAR-US

GROSS PRIV DOM INVEST-CH IN PRIV INVENT-FARM,BILLIONS OF \$,SAAR-US

HOUSING STARTS:NONFARM(1947-58);TOTAL FARM\&NONFARM(1959-)(THOUS.,SA

MOBILE HOMES: MANUFACTURERS' SHIPMENTS (THOUS.OF UNITS,SAAR)

NAPM INVENTORIES INDEX (PERCENT)

NAPM NEW ORDERS INDEX (PERCENT)

NAPM VENDOR DELIVERIES INDEX (PERCENT)

NEW ORDERS (NET) - CONSUMER GOODS \& MATERIALS, 1996 DOLLARS (BCI)

NEW ORDERS, NONDEFENSE CAPITAL GOODS, IN 1996 DOLLARS (BCI)

IMPORTS OF GDS\&SVC,BILLIONS OF \$,SAAR-US

EXPORTS OF GDS\&SVC,BILLIONS OF \$,SAAR-US

S\&P'S COMMON STOCK PRICE INDEX: COMPOSITE (1941-43=10)

S\&P'S COMMON STOCK PRICE INDEX: INDUSTRIALS (1941-43=10)

S\&P'S COMPOSITE COMMON STOCK: DIVIDEND YIELD (\% PER ANNUM)

S\&P'S COMPOSITE COMMON STOCK: PRICE-EARNINGS RATIO (\%,NSA)

FOREIGN EXCHANGE RATE: UNITED KINGDOM (CENTS PER POUND)

FOREIGN EXCHANGE RATE: CANADA (CANADIAN \$ PER U.S.\$)

INTEREST RATE: U.S.TREASURY BILLS,SEC MKT,3-MO.(\% PER ANN,NSA)

INTEREST RATE: U.S.TREASURY BILLS,SEC MKT,6-MO.(\% PER ANN,NSA)

INTEREST RATE: U.S.TREASURY CONST MATURITIES,1-YR.(\% PER ANN,NSA)

INTEREST RATE: U.S.TREASURY CONST MATURITIES,5-YR.(\% PER ANN,NSA)

INTEREST RATE: U.S.TREASURY CONST MATURITIES,10-YR.(\% PER ANN,NSA)

BOND YIELD: MOODY'S AAA CORPORATE (\% PER ANNUM)

BOND YIELD: MOODY'S BAA CORPORATE (\% PER ANNUM) 


\begin{tabular}{|c|c|}
\hline 75 & FYGT1-FYFF \\
\hline 76 & FYGT5-FYFF \\
\hline 77 & FYGT10-FYFF \\
\hline 78 & FYAAAC-FYFF \\
\hline 79 & FYBAAC-FYFF \\
\hline 80 & BASIC:FM1.M \\
\hline 81 & BASIC:FM2.M \\
\hline 82 & USCEN:MNY2@00.M \\
\hline 83 & BASIC:FMFBA.M \\
\hline 84 & BASIC:FMRRA.M \\
\hline 85 & BASIC:FMRNBA.M \\
\hline 86 & USCEN:ALCIBLO0Z.M \\
\hline 87 & BASIC:FCLBMC.M \\
\hline 88 & BASIC:CCINRV.M \\
\hline 89 & DRIINTL:PGDP@US.Q \\
\hline 90 & DRIINTL:PCP@US.Q \\
\hline 91 & USCEN:PDII.Q \\
\hline 92 & USCEN:JPCD.Q \\
\hline 93 & USCEN:JPCN.Q \\
\hline 94 & USCEN:JPCSV.Q \\
\hline 95 & BASIC:PUXM.M \\
\hline 96 & BASIC:PUXHS.M \\
\hline 97 & BASIC:PUXF.M \\
\hline 98 & BASIC:PUS.M \\
\hline 99 & BASIC:PUCD.M \\
\hline 100 & BASIC:PUC.M \\
\hline 101 & BASIC:PUNEW.M \\
\hline 102 & BASIC:PWFSA.M \\
\hline 103 & BASIC:PMCP.M \\
\hline 104 & UOMO83 \\
\hline 105 & DRIINTL:JLEAD@US.Q \\
\hline 106 & DRIINTL:JLAG@US.Q \\
\hline 107 & DRIINTL:JCOIN@US.Q \\
\hline 108 & FYBAAC-FYGT10.M \\
\hline 109 & USCEN:NC16\&Z.M \\
\hline 110 & BASIC:FYFF.M \\
\hline
\end{tabular}

MONEY STOCK: M1(CURR,TRAV.CKS,DEM DEP,OTHER CK'ABLE DEP)(BIL\$,SA) MONEY STOCK:M2(M1+O’NITE RPS,EURO\$,G/P\&B/D MMMFS\&SAV\&SM TIME DEP(BIL\$) MONEY SUPPL-M2 IN 2000 \$,SA-US MONETARY BASE, ADJ FOR RESERVE REQUIREMENT CHANGES(MIL\$,SA) DEPOSITORY INST RESERVES:TOTAL,ADJ FOR RESERVE REQ CHGS(MIL\$,SA) DEPOSITORY INST RESERVES:NONBORROWED,ADJ RES REQ CHGS(MIL\$,SA) COML\&IND LOANS OUTST,SA-US WKLY RP LG COM'L BANKS:NET CHANGE COM'L \& INDUS LOANS(BIL\$,SAAR) CONSUMER CREDIT OUTSTANDING - NONREVOLVING(G19) NIA PRICE DEFLATOR - GROSS DOMESTIC PRODUCT, SA - U.S. NIA PRICE DEFLATOR - PRIVATE CONSUMPTION EXPENDITURE, SA - U.S. GROSS PRIV DOM INVEST,PRICE DEFLATORS $(2000=100)$,SA,SA-US PCE-DUR,PRICE INDEX $(2000=100)$,SA,SA-US PCE-NDUR,PRICE INDEX $(2000=100)$, SA,SA-US PCE-SVC,PRICE INDEX $(2000=100)$,SA,SA-US CPI-U: ALL ITEMS LESS MEDICAL CARE (82-84=100,SA) CPI-U: ALL ITEMS LESS SHELTER (82-84=100,SA)

CPI-U: ALL ITEMS LESS FOOD $(82-84=100, \mathrm{SA})$

CPI-U: SERVICES $(82-84=100, \mathrm{SA})$

CPI-U: DURABLES $(82-84=100, \mathrm{SA})$

CPI-U: COMMODITIES $(82-84=100, \mathrm{SA})$

CPI-U: ALL ITEMS (82-84=100,SA)

PRODUCER PRICE INDEX: FINISHED GOODS $(82=100, \mathrm{SA})$ NAPM COMMODITY PRICES INDEX (PERCENT) COMPONENT INDEX OF CONSUMER EXPECTATIONS, NSA, CONFBOARD AND U.MICH. COMPOSITE CYCLICAL INDICATOR (1996) - LEADING, SA - U.S. COMPOSITE CYCLICAL INDICATOR (1996) - LAGGING, SA - U.S. COMPOSITE CYCLICAL INDICATOR (1996) - COINCIDENT, SA - U.S. BAA SPREAD

CIVILIAN NONINSTITUTIONAL POP: 16 YEARS\&OVER,SA-US INTEREST RATE: FEDERAL FUNDS (EFFECTIVE) (\% PER ANNUM,NSA) 


\section{References}

[1] Adrian, T. and Ashcraft, A.B. (2012) "Shadow Banking Regulation", Federal Reserve Bank of New York, Staff Report N. 559.

[2] Adrian, T. and Shin, H.S. (2011a) "Financial Intermediary Balance Sheet Management" Annual Review of Financial Economics, 3, 289-307.

[3] Adrian, T. and Shin, H.S. (2011b) "Financial Intermediaries and Monetary Economics" Ch. 12 in the Handbook of Monetary Economics (eds) Benjamin Friedman and Michael Woodford, Elsevier. 2011

[4] Adrian, T. and Shin, H.S. (2010) "The Changing Nature of Financial Intermediation and the Financial Crisis of 2007-2009". Annual Review of Economics. 2:603-18.

[5] Allen, F. and Gale, D. (2000) "Financial Contagion". The Journal of Political Economy, 108(1): 1-33.

[6] Altunbas, Yener, Gambacorta, Leonardo and Marques-Ibanez, David (2009) "Securitisation and the bank lending channel," European Economic Review, 53(8): 996-1009.

[7] Bai, J., and S. Ng (2002), "Determining the Number of Factors in Approximate Factor Models," Econometrica 70:1,191-221.

[8] Bernanke, B.S. and Gertler, M. (1995) "Inside the Blanck Box: The Credit Channel of Monetary Policy Transmission". Journal of Economic Perspectives. 9(4). Fall 1995: 27-48

[9] Bernanke, B.S., J. Boivin and P. Eliasz (2005), "Measuring the Effects of Monetary Policy: a Factor-augmented Vector Autoregressive (FAVAR) Approach," Quarterly Journal of Economics 120: 387-422.

[10] Boivin, J., and Giannoni, M.(2006) "Has Monetary Policy Become More Effective?", The Review of Economics and Statistics 88(3): 445-462. 
[11] Boivin, J., Kiley M. T. and Mishkin, F.S. (2011) "How has the monetary transmission mechanism evolved over time?" Ch. 8 in the Handbook of Monetary Economics (eds) Benjamin Friedman and Michael Woodford, Elsevier. 2011

[12] Borio, c. and Zhu, H. (2012) "Capital Regulation, risk-taking and monetary policy: a missing link in the transmission mechanism?," Journal of Financial Stability, 8(4): 236251.

[13] Brunnermeier, M. Dong,G. and Paliab, D. (2012) "Banks' Non-Interest Income and Systemic Risk," mimeo

[14] Bruno, V. and Shin, H.S. (2013) "Capital Flows and the Risk-taking channel of monetary policy", NBER w.p. 18942.

[15] Diamond, D. W. and Dybvig, P. H. (1983) "Bank Runs, Deposit Insurance, and Liquidity". The Journal of Political Economy, 91(3): 401-419.

[16] Diebold F. X. and Yilmaz K. (2012) "Better to Give than to Receive: Predictive Directional Measurement of Volatility Spillovers (with discussion)," International Journal of Forecasting, 28, 57-66.

[17] Diebold F. X. and Yilmaz K. (2013) "On the Network Topology of Variance Decompositions: Measuring the Connectedness of Financial Firms," Journal of Econometrics, forthcoming.

[18] Dynan K, Elmendorf D.W. and Sichel D.E. (2006) "Can Financial Innovation Help to Explain the Reduced Volatility of Economic Activity?" Journal of Monetary Economics 53: 123.

[19] Gennaioli, N., Shleifer, A. and R. Vishny (2013). "Finance and the Preservation of Wealth", mimeo

[20] Gennaioli, N., Shleifer, A. and R. Vishny (2012). "Money Doctors", mimeo 
[21] Greenwood, R. and Scharfstein, D. (2013) "The Growth of Modern Finance". Journal of Economic Perspectives, 27(2): 3-28.

[22] Gorton, G. (2009) "The Panic of 2007," in Maintaining Stability in a Changing Financial System, Proceedings of the 2008 Jackson Hole Conference, Federal Reserve Bank of Kansas City.

[23] Gorton, G., and Metrik, A. (2012) "Securitization" in The Handbook of the Economics of Finance, ed. G. Constantinides, M. Harris, and R. Stulz, forthcoming.

[24] Gorton, G., and A. Winton (2003): "Financial Intermediation," in Handbook of the Economics of Finance, ed. by G. M. Constantinides, M. Harris, and R. Stulz, pp. 431-552, North Holland. Elsevier.

[25] Hahm, H.J., Shin, H.S. and Shin, K. (forthcoming) "Non-Core Bank Liabilities and Financial Vulnerability", Journal of Money, Credit and Banking.

[26] Hobjin, B. and Ravenna, F (2010) "Loan Securitization and the Monetary Transmission Mechanism", mimeo.

[27] Keys,B.,Mukherjee, T, Seru, A. and V. Vig (2010) "Did Securitization Lead to Lax Screening? Evidence From Subprime Loans", The Quarterly Journal of Economics, 125(1): 307-362.

[28] Mesonnier J.-S. and Stevanovic D. (2012), "Bank Leverage Shocks and the Macroeconomy: a New Look in a Data-rich Environment," Working Paper 394, Banque de France

[29] Moran, K. and Meh, C (2013) "Shadow Banking and Regulation: a Quantitative Assessment". Mimeo.

[30] Ng, S. and D. Stevanovic (2012), "Factor-augmented Autoregressive Distributed Lag Models," mimeo, Columbia University.

[31] Ordonez, G and Gorton, G (2012) "Collateral Crises" NBER Working Paper n.17771. 
[32] Philippon, T. (2012) "Has the US Finance Industry Become Less Efficient?", mimeo.

[33] Philippon, T. and Reshef, A. (forthcoming) "Wages and Human Capital in the U.S. Financial Industry: 1909-2006", Quarterly Journal of Economics.

[34] Philippon, T. and Reshef, A. (2013) "An international look at the growth of modern finance." Journal of Economic Perspectives, 27(2): 73-96.

[35] Pozsar, Z., Adrian, T. Ashcraft, A. and Boesky, H. (2012) "Shadow Banking", Federal Reserve Bank of New York, Staff Report N. 458. 
Figure 1: Asset Shares of Different Actors (source: FED Flow of Funds)

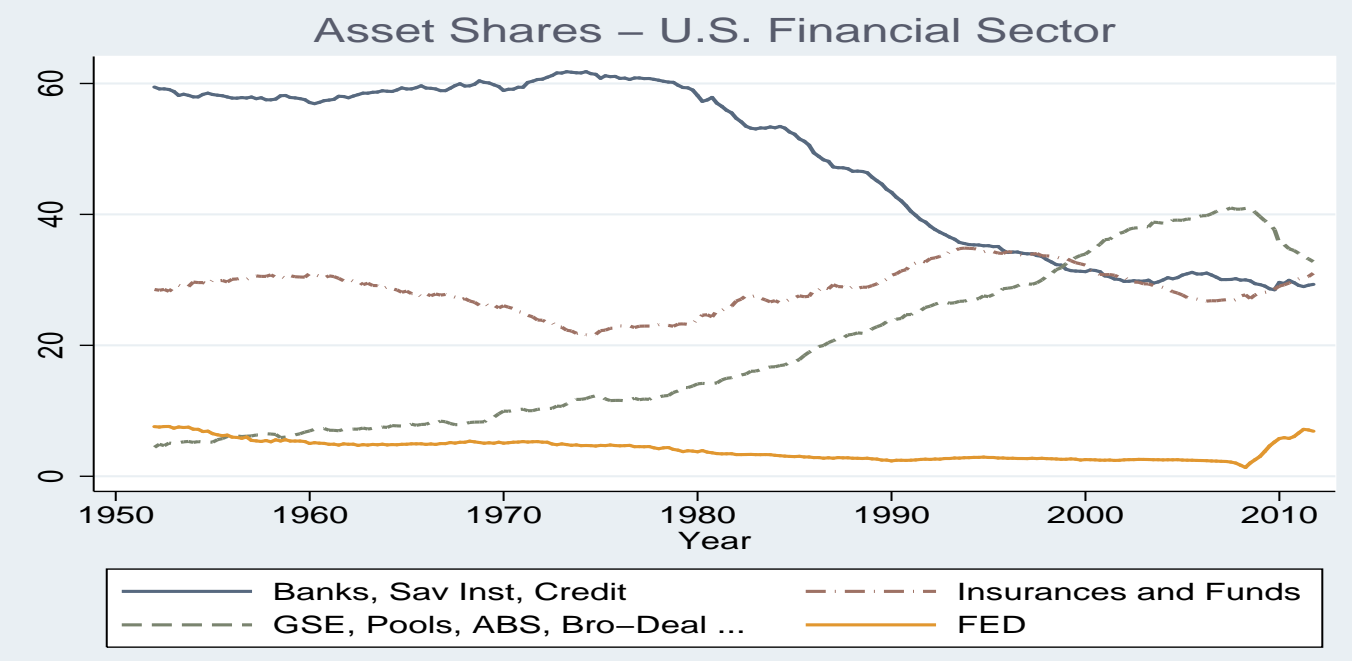

Figure 2: The Measure of Connectedness: U.S. 1952-2009, Traditional Actors Measure of Connectedness, Traditional Actors

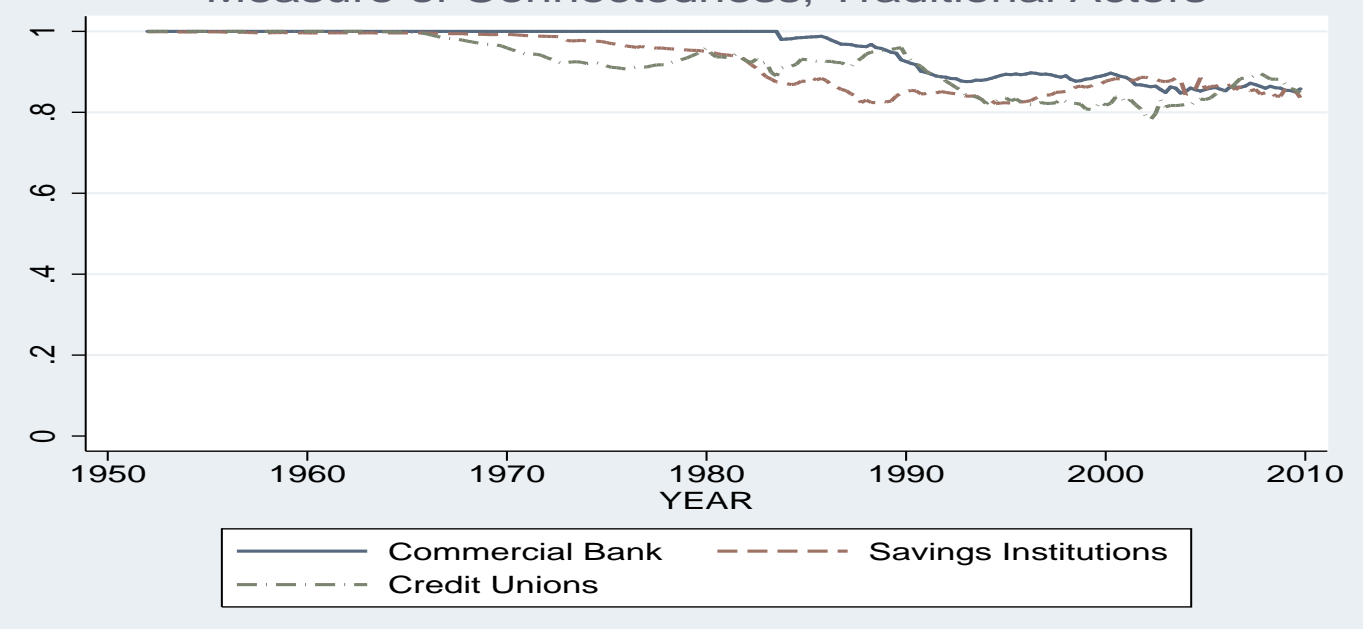


Figure 3: The Measure of Connectedness: U.S. 1952-2009, Insurance Companies and Mutual Funds

Measure of Connectedness, Mutual Funds and Ins. Comp.

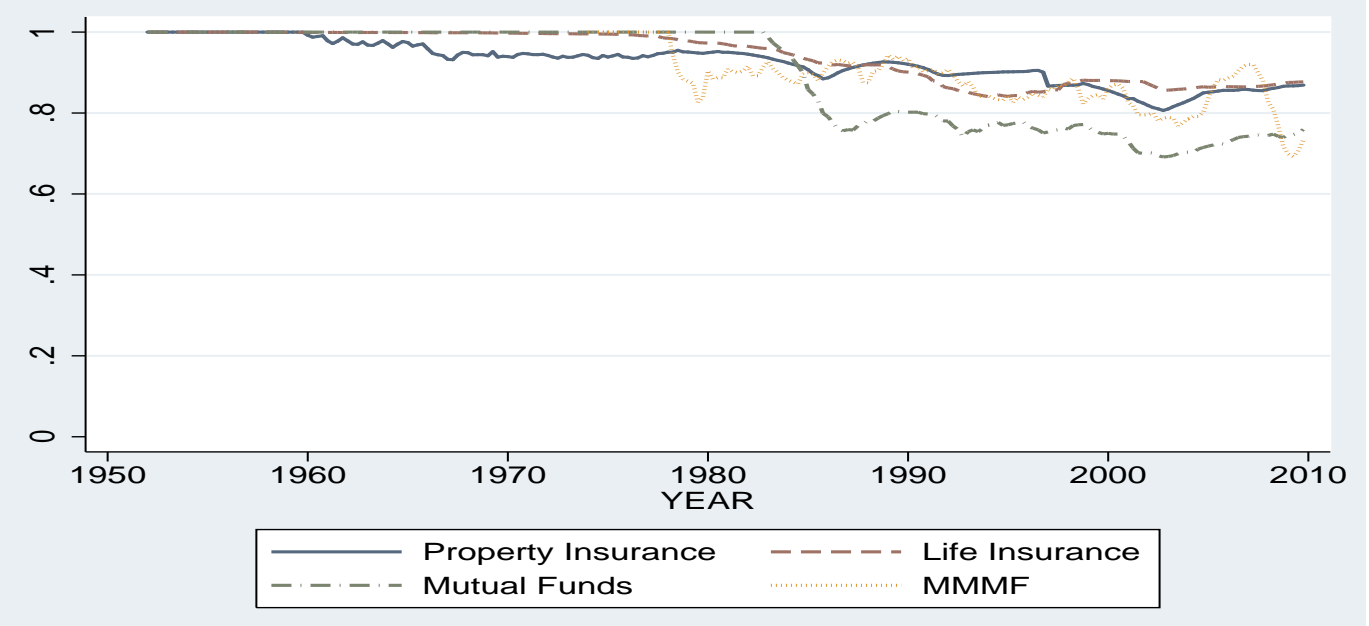

Figure 4: The Measure of Connectedness: U.S. 1952-2009, Pension Funds

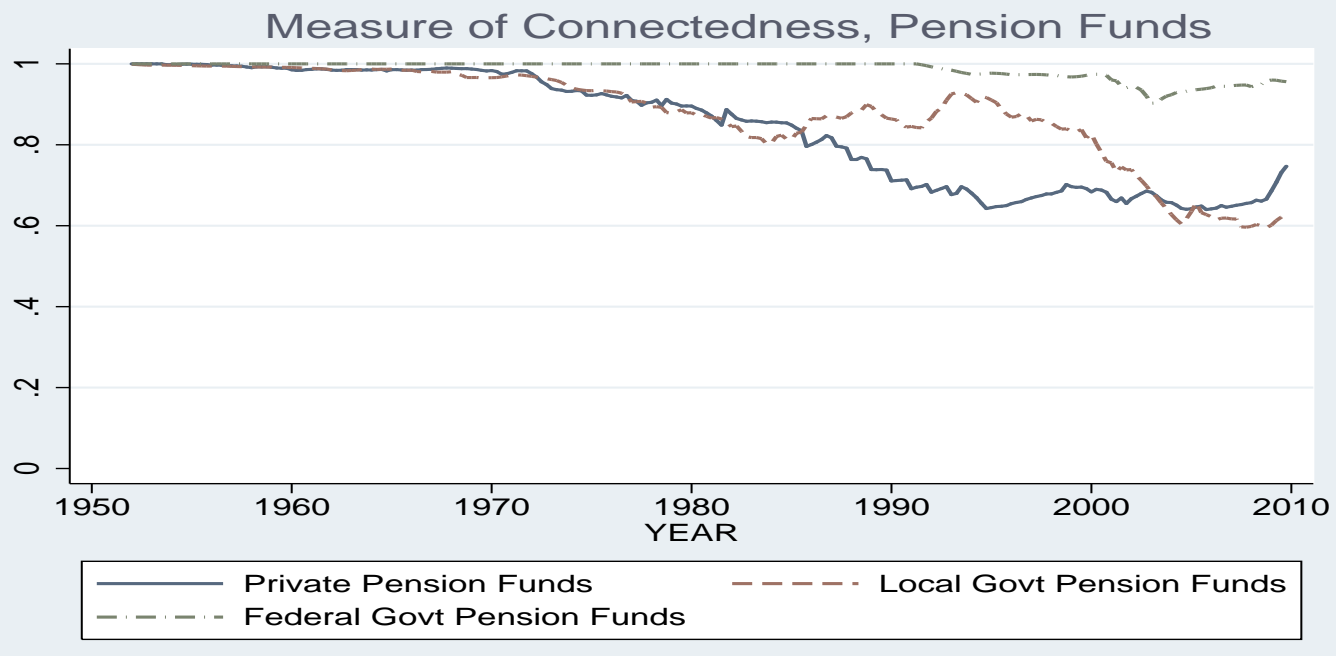


Figure 5: The Measure of Connectedness: U.S. 1952-2009, Shadow Banking

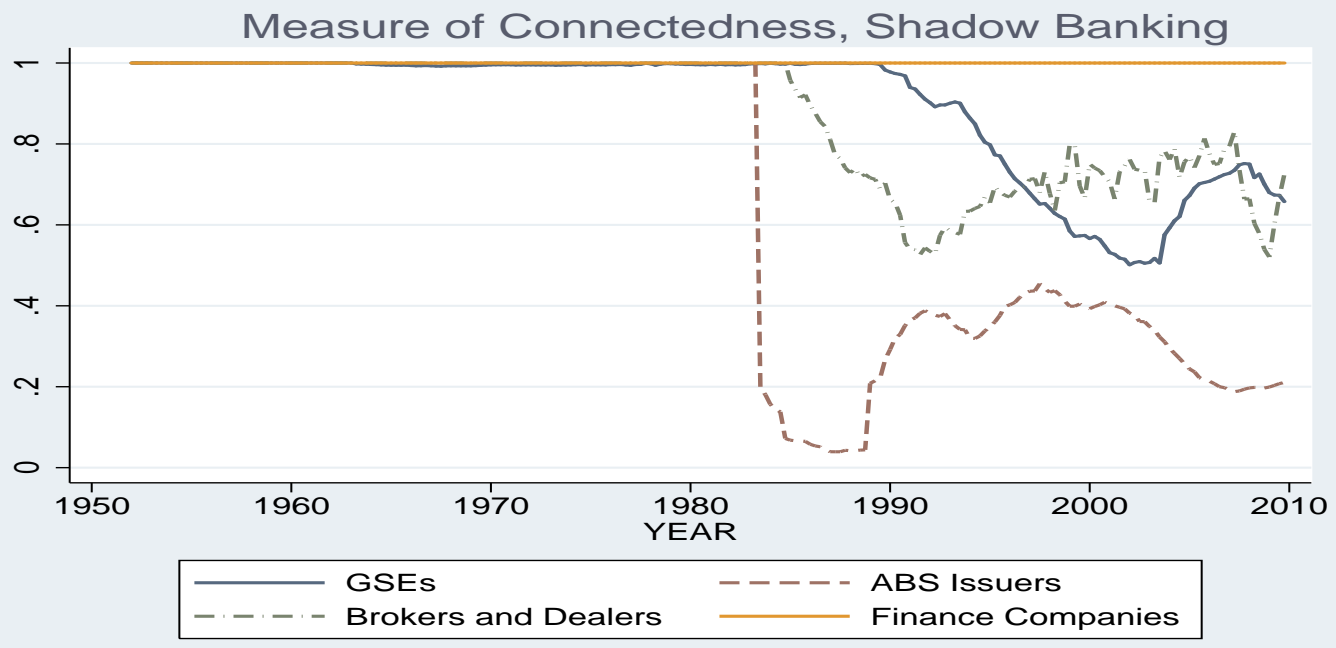

Figure 6: The Measure of Connectedness: U.S. 1952-2009 Measure of Connectedness, Aggregate

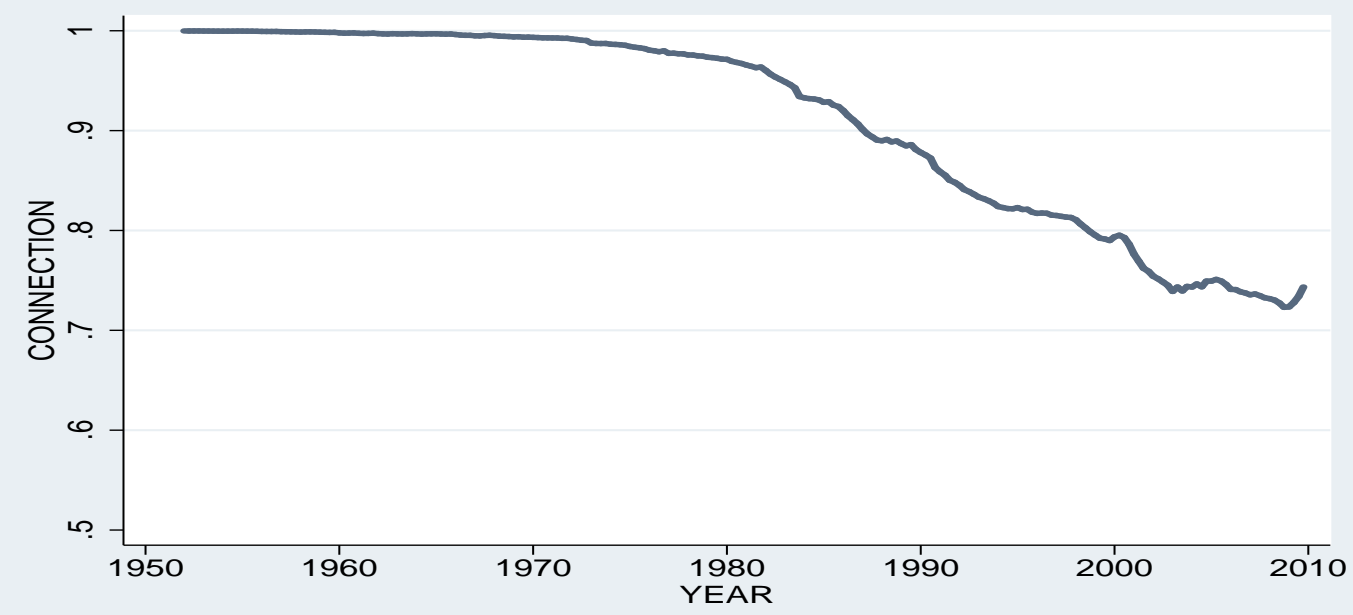


Figure 7: Shares of Credit Market Instruments

Credit Market Instruments Share, U.S. Financial Industry

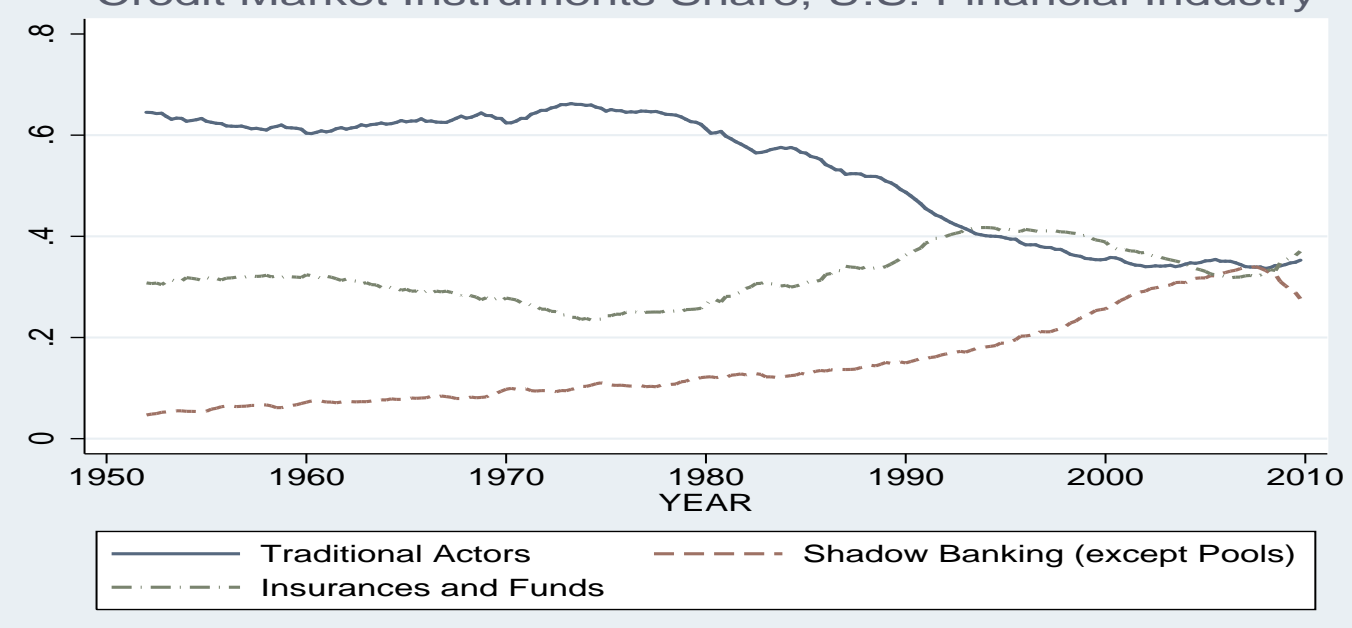

Figure 8: Shares of Credit Market Instruments Credit Market Instruments Share, Selected Institutions

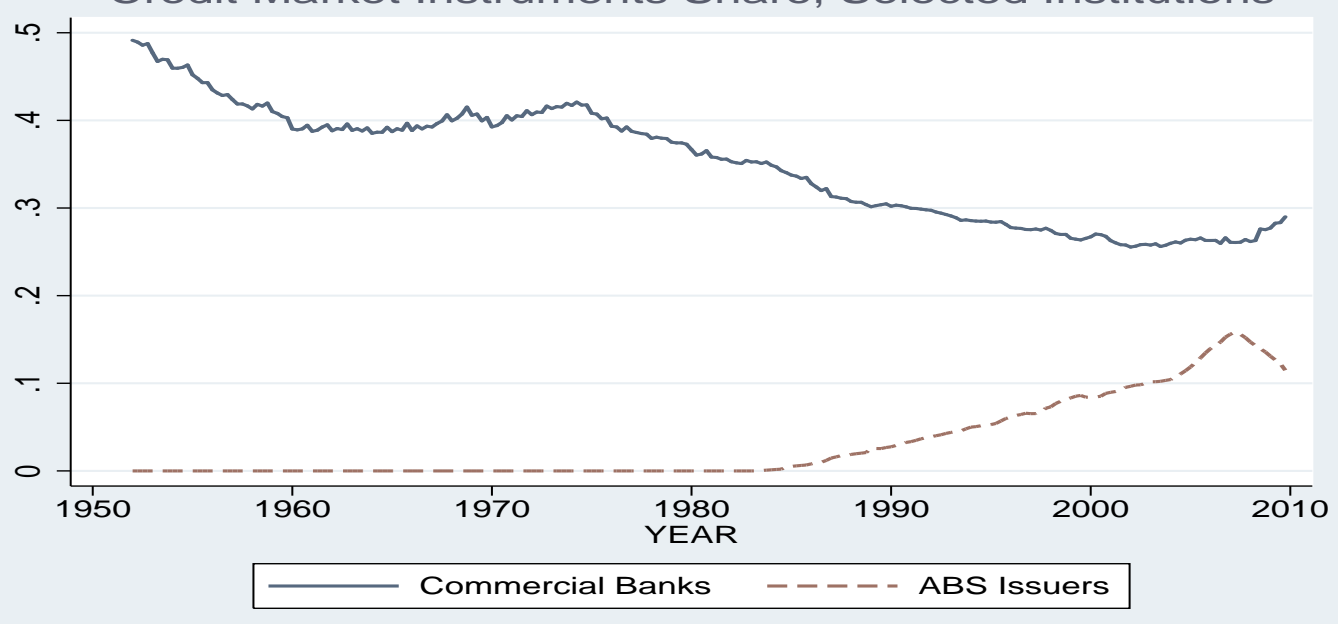


Figure 9: Measure of Connectedness and Share of Finance in GDP (Philippon 2012)

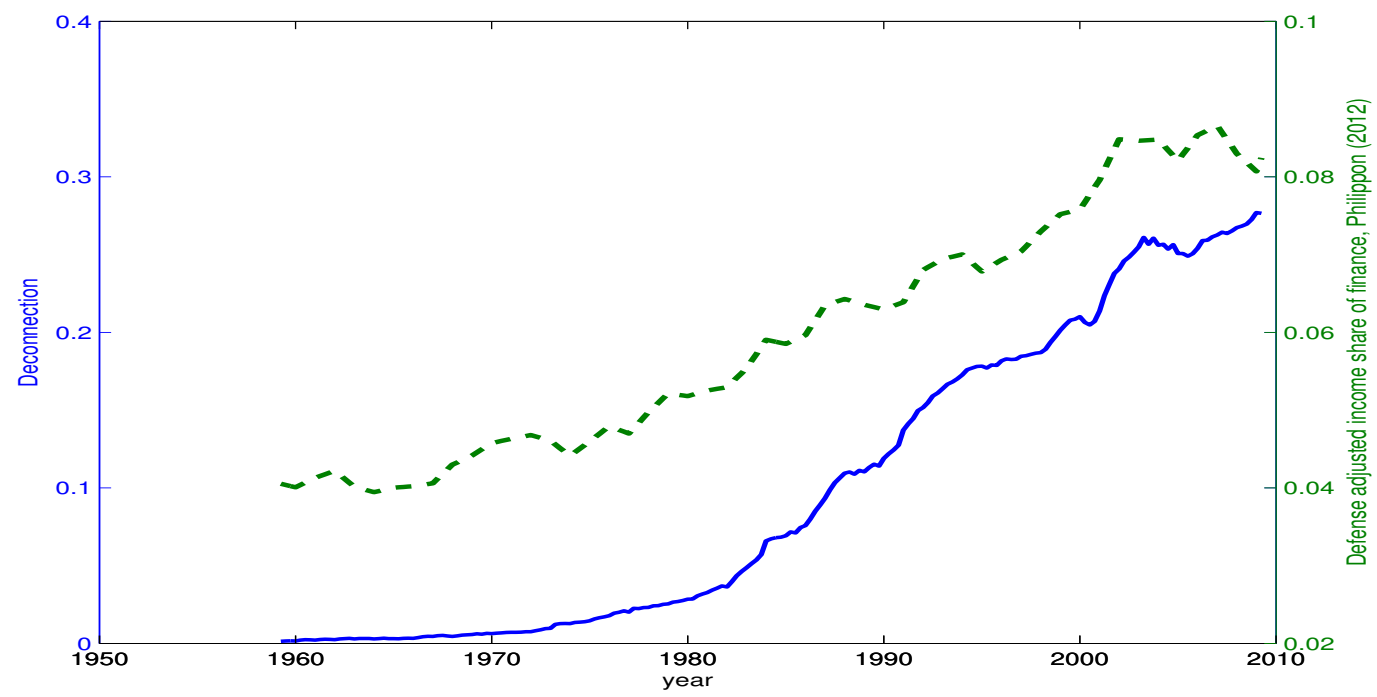

Figure 10: Comparison of IRFs to a monetary policy shock conditional on different degrees of Connectedness in SVAR
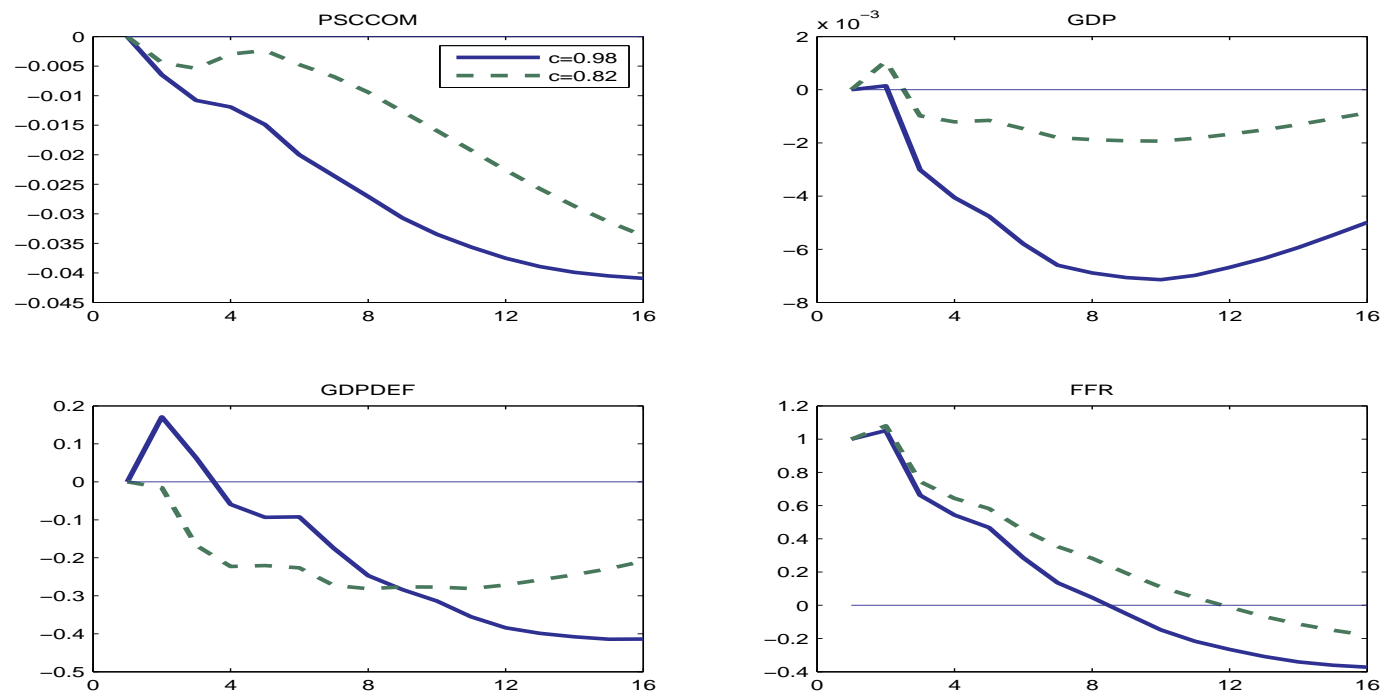
Figure 11: IRFs to a monetary policy shock with $C=0.98$ in SVAR
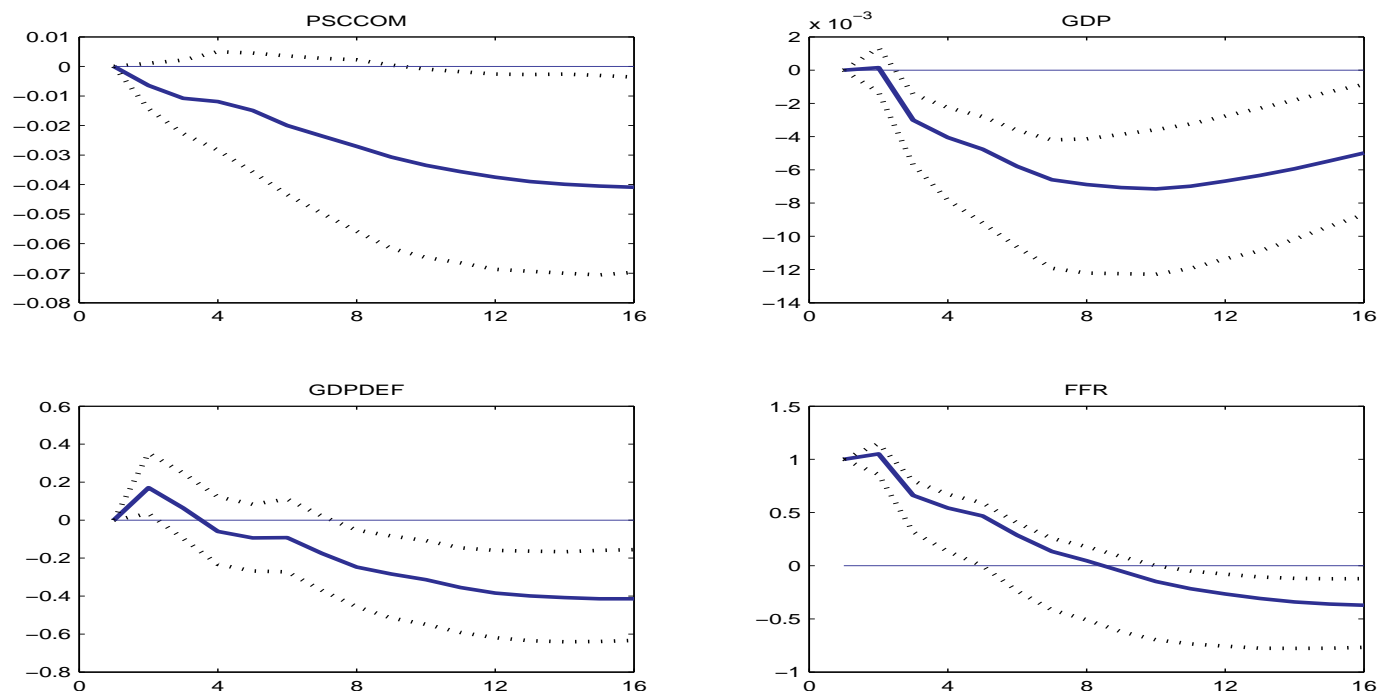

Figure 12: IRFs to a monetary policy shock with $C=0.82$ in SVAR
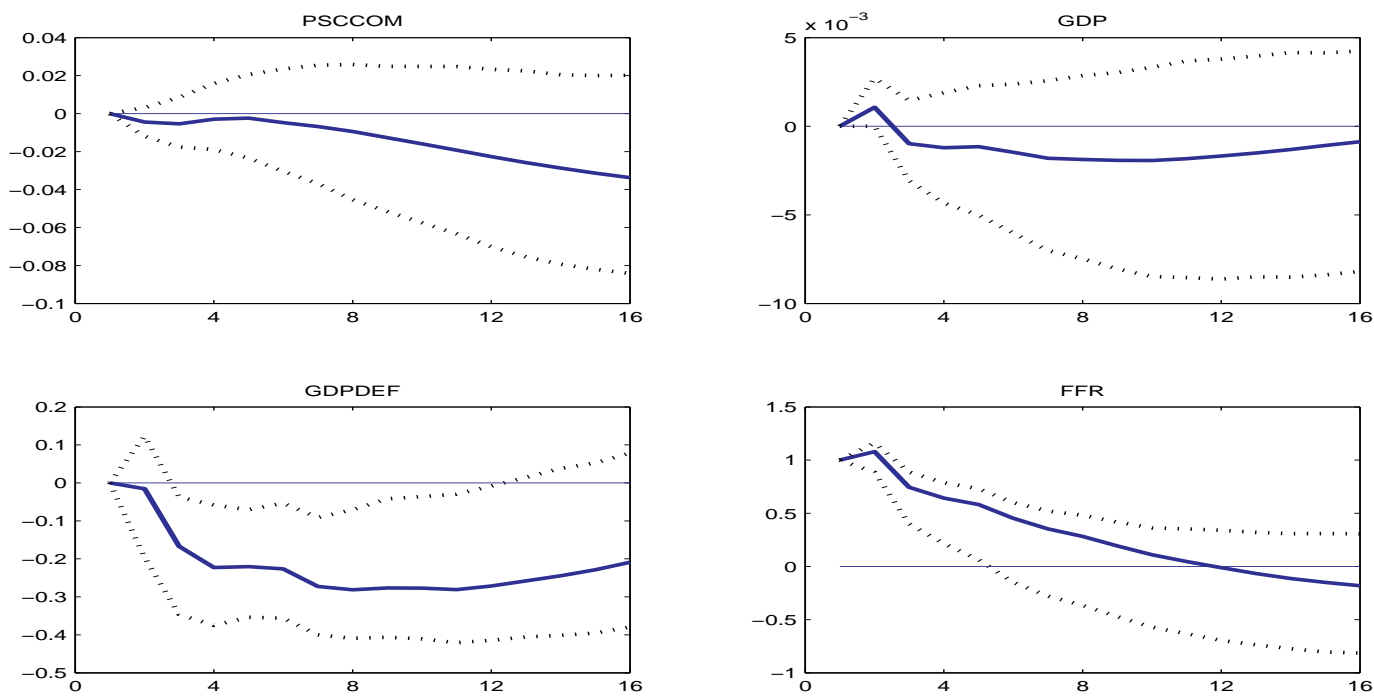
Figure 13: Difference between IRFs to a monetary policy shock with different levels of Connectedness
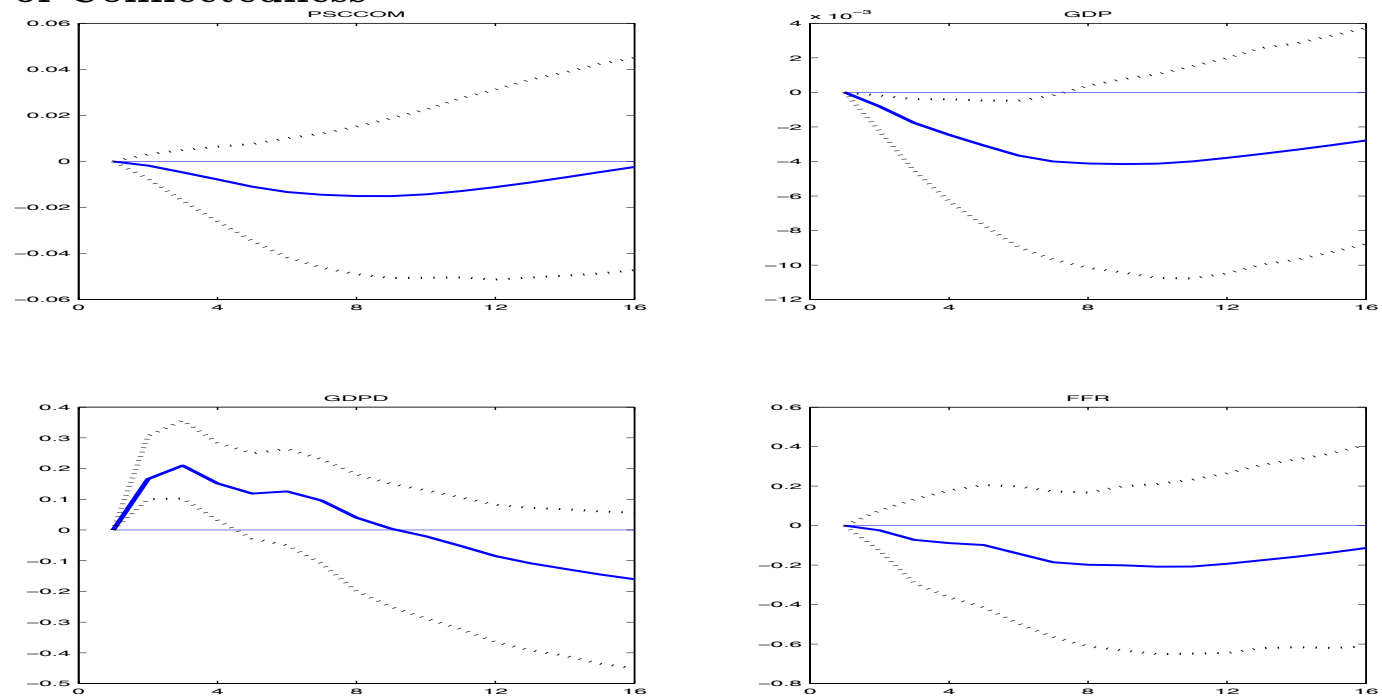

Figure 14: Comparison of IRFs to a monetary policy shock in FAVAR, $C=0.98$ and $C=0.82$, Real Variables
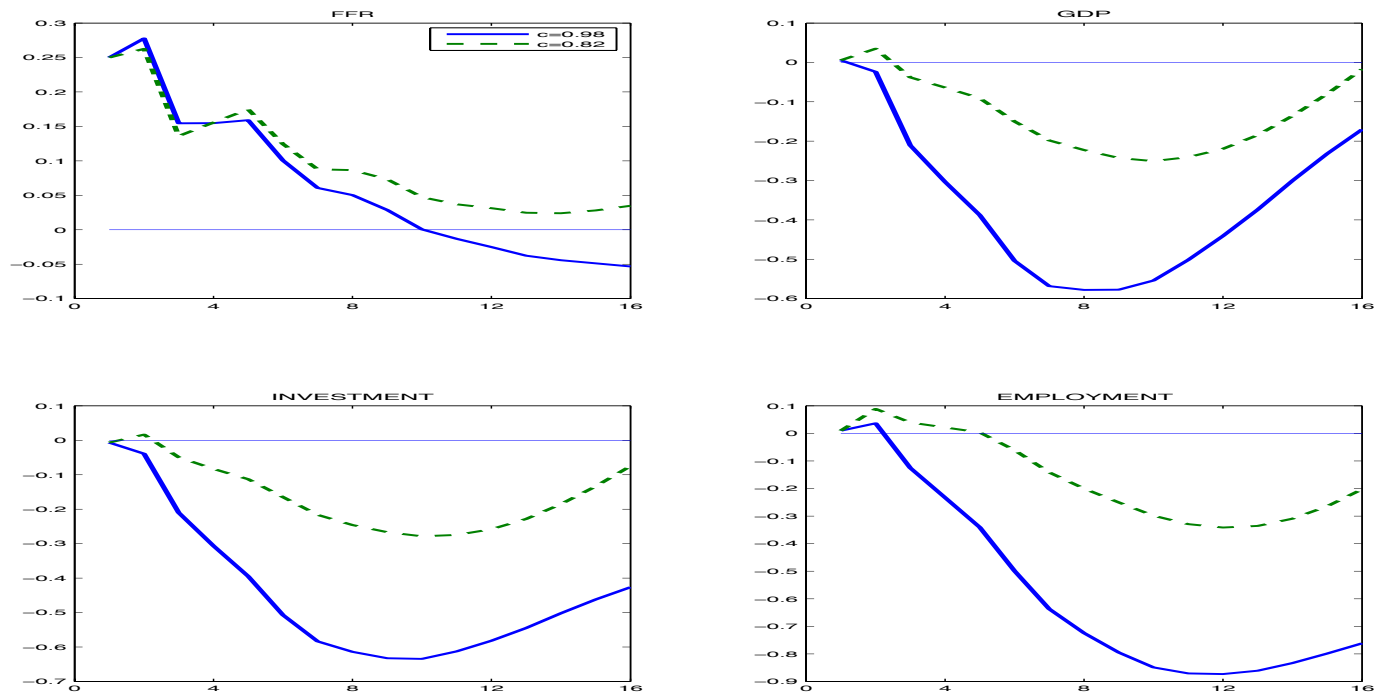
Figure 15: Difference between IRFs to a monetary policy shock with different levels of Connectedness, FAVAR Real Variables
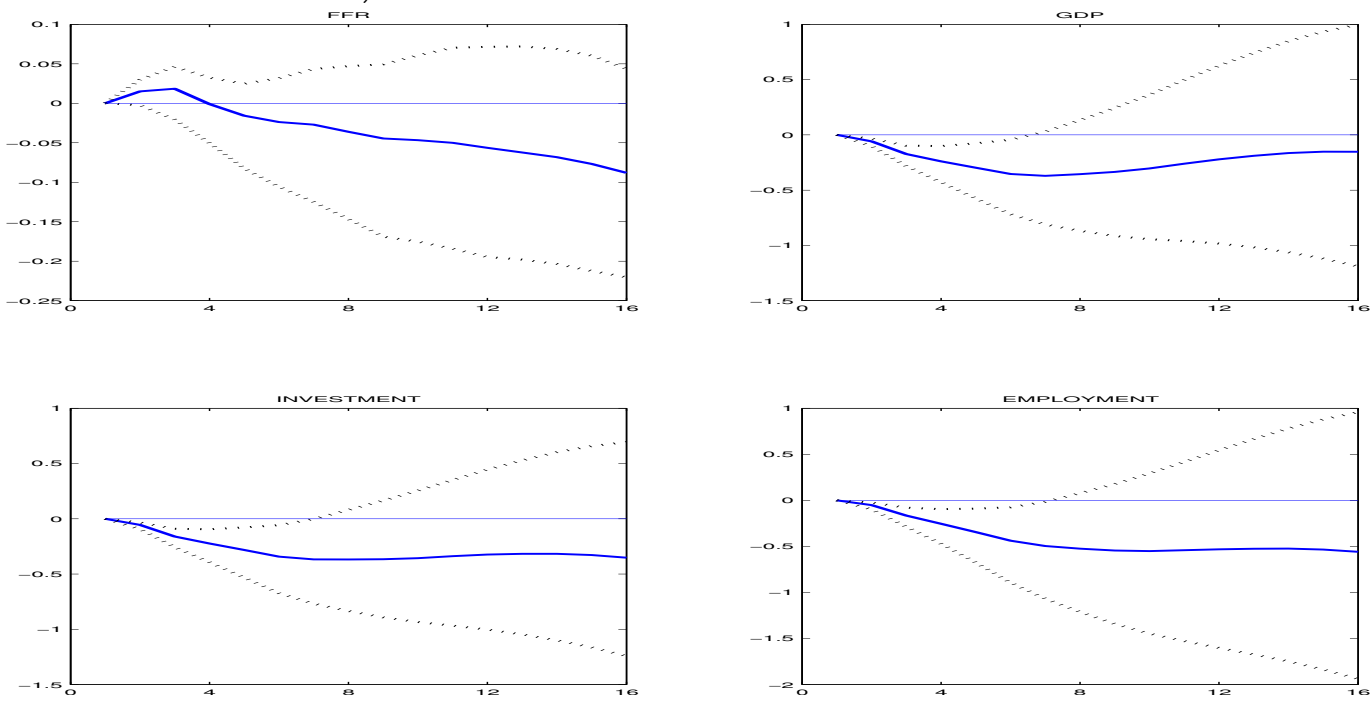

Figure 16: Comparison of IRFs to a monetary policy shock in FAVAR, $C=0.98$ and $C=0.82$, Financial Variables
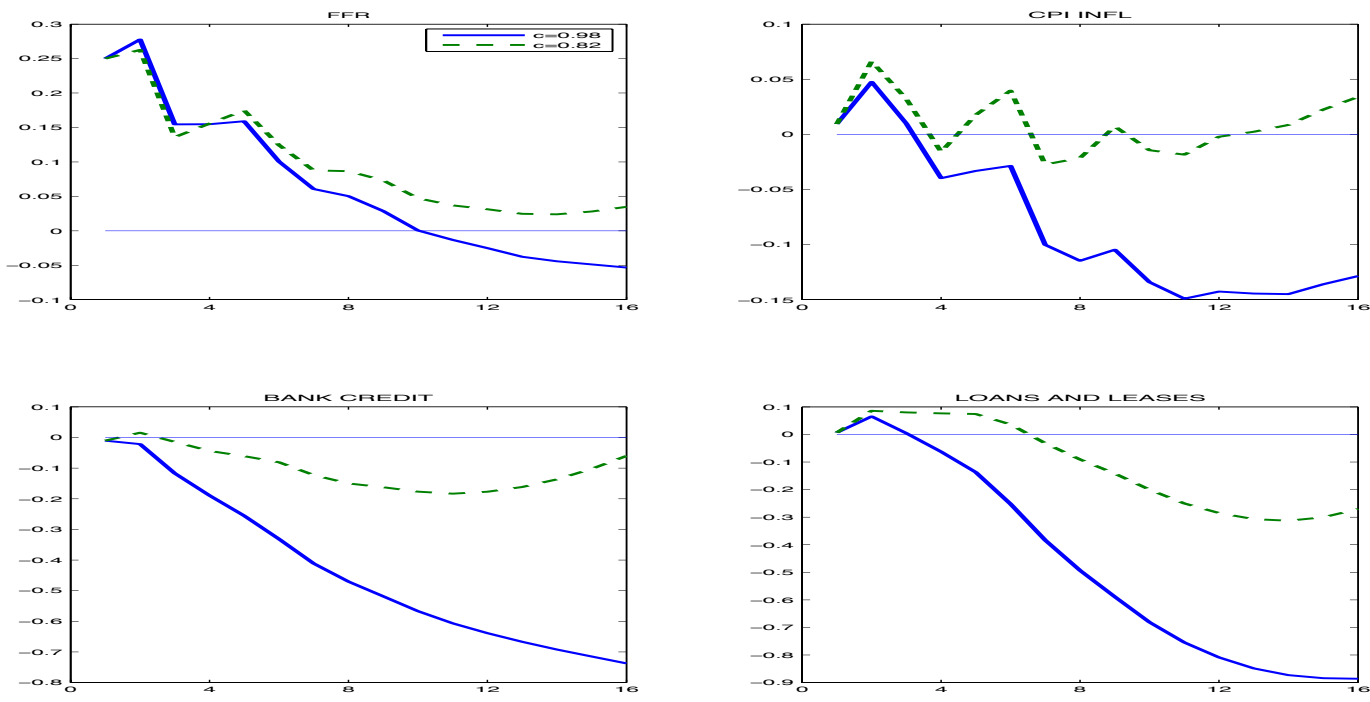
Figure 17: Difference between IRFs to a monetary policy shock with different levels of Connectedness, FAVAR Financial Variables
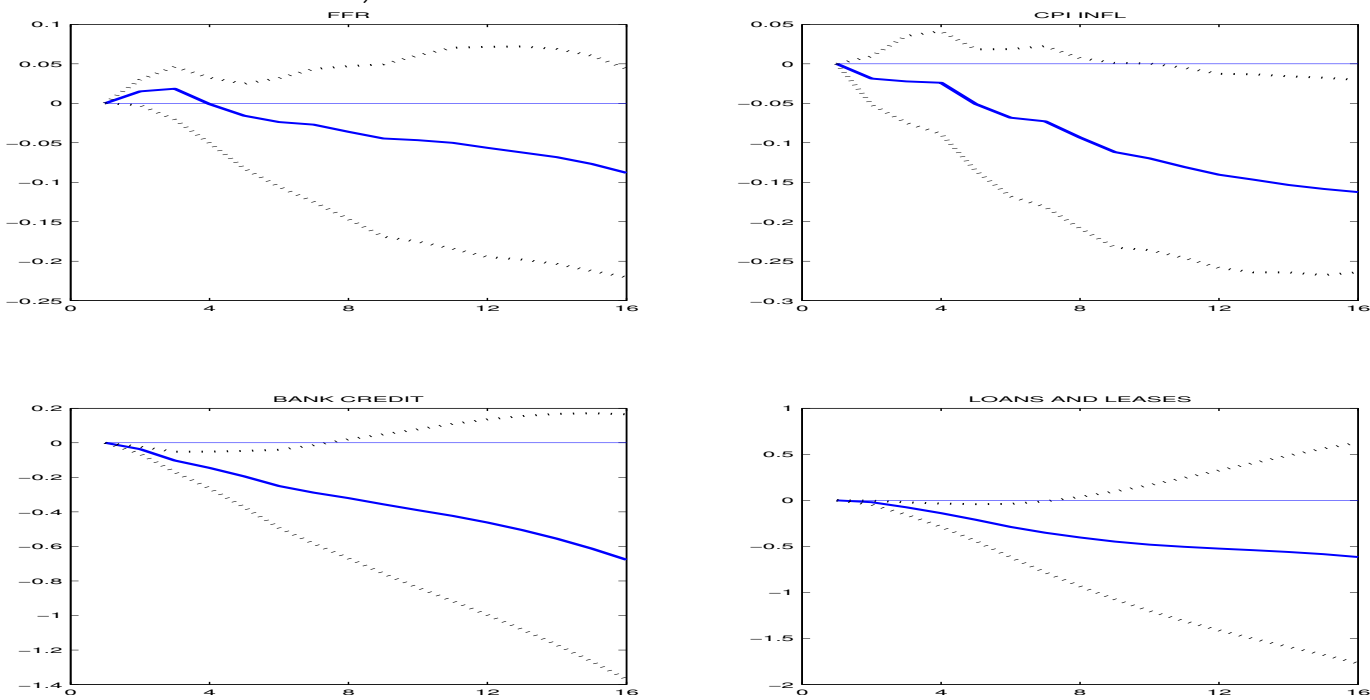